This item was submitted to Loughborough's Research Repository by the author.

Items in Figshare are protected by copyright, with all rights reserved, unless otherwise indicated.

\title{
The influence of natural flow regimes on macroinvertebrate assemblages in a semiarid Mediterranean basin
}

PLEASE CITE THE PUBLISHED VERSION

http://dx.doi.org/10.1002/eco.1274

\section{PUBLISHER}

(c) John Wiley \& Sons, Ltd.

\section{VERSION}

AM (Accepted Manuscript)

\section{PUBLISHER STATEMENT}

This work is made available according to the conditions of the Creative Commons Attribution-NonCommercialNoDerivatives 4.0 International (CC BY-NC-ND 4.0) licence. Full details of this licence are available at: https://creativecommons.org/licenses/by-nc-nd/4.0/

\section{LICENCE}

CC BY-NC-ND 4.0

\section{REPOSITORY RECORD}

Belmar, O., J. Velasco, C. Gutierrez-Canovas, A. Mellado-Diaz, A. Millan, and Paul J. Wood. 2019. "The Influence of Natural Flow Regimes on Macroinvertebrate Assemblages in a Semiarid Mediterranean Basin". figshare. https://hdl.handle.net/2134/17358. 


\section{The influence of natural flow regimes on macroinvertebrate assemblages in a semiarid Mediterranean basin.}

\begin{tabular}{|r|l|}
\hline Journal: & Ecohydrology \\
\hline Manuscript ID: & ECO-11-0181.R1 \\
\hline Wiley - Manuscript type: & Research Article \\
\hline Date Submitted by the Author: & 10 -Apr-2012 \\
\hline Complete List of Authors: & $\begin{array}{r}\text { Belmar, Oscar; University of Murcia, Ecology and Hydrology } \\
\text { Velasco, Josefa; University of Murcia, Ecology and Hydrology } \\
\text { Gutierrez-Canovas, Cayetano; University of Murcia, Ecology and Hydrology } \\
\text { Mellado, Andres; Centro de Estudios Hidrograficos CEDEX, } \\
\text { Wood, Paul; Loughborough University, Geography; }\end{array}$ \\
\hline Keywords: & $\begin{array}{l}\text { natural flow regime, flow stability, minimum flows, macroinvertebrate } \\
\text { composition, richness, Segura River Basin, semiarid Mediterranean streams }\end{array}$ \\
\hline
\end{tabular}


The influence of natural flow regimes on macroinvertebrate assemblages in a semiarid Mediterranean basin.

O. Belmar*, J. Velasco*, C. Gutiérrez-Cánovas*, A. Mellado-Díaz**, A. Millán* P.J. Wood***.

* Department of Ecology and Hydrology. University of Murcia. Espinardo Campus. 30100. Murcia (Spain).

** Centro de Estudios Hidrográficos CEDEX. Paseo Bajo de la Virgen del Puerto 3. 28005. Madrid (Spain).

*** Department of Geography. Loughborough University, Leicestershire, UK. 
2 The investigation of flow-ecology relationships constitutes the basis for the 3 development of environmental flow criteria. The need to understand hydrology-ecology 4 linkages in natural systems has increased due to the prospect of climate change and flow 5 regime management, especially in water-scarce areas such as Mediterranean basins. Our

6 research quantified the macroinvertebrate community response at family, genus and 7 species level to natural flow regime dynamics in freshwater streams of a Mediterranean 8 semiarid basin (Segura River, SE Spain), and identified the flow components that 9 influence the composition and richness of biotic assemblages. Flow stability and 10 minimum flows were the principal hydrological drivers of macroinvertebrate 11 assemblages, whereas the magnitude of average and maximum flows had a limited 12 effect. Perennial stable streams were characterised by flow sensitive lotic taxa 13 (Ephemeroptera, Plecoptera, Tricoptera) and intermittent streams by predominately 14 lentic taxa (Odonata, Coleoptera, Heteroptera and Diptera). Relatively minor biological 15 changes were recorded for intermediate flow regime classes along a gradient of flow 16 stability. Seasonal variation and minimum flows are key hydrological components that 17 need to be considered for river management and environmental flows in the Segura 18 River Basin and other Mediterranean basins. The anthropogenic modification of these 19 parameters, due to both human activities and climate change, would probably lead to 20 significant changes in the structure and composition of communities in perennial stable 21 streams. This would be characterised by a reduction of flow sensitive EPT taxa and an increase in more resilient OCHD taxa.

Key words: natural flow regime, flow stability, minimum flows, macroinvertebrate composition, richness, Segura River Basin, semiarid Mediterranean streams

\section{Introduction}

The search for links between instream ecology and hydrology has become one of the 30 fundamental issues in contemporary river science (Vaughan et al., 2009). Empirical investigation of regional flow-ecology relationships constitutes the basis for the 32 development of environmental flow (e-flow) criteria (Arthington et al., 2006; Poff et 33 al., 2010). In addition, the need to understand ecology-hydrology linkages in natural 34 systems has been highlighted by the need to define reference conditions against which 
1 modified dynamics can be compared (Tockner et al., 2003). These needs are

2 particularly pressing in the light of predicted climate change (European Environment

3 Agency, 2008) and anthropogenic modification of natural flow regimes, especially in

4 water-scarce areas such as Mediterranean basins.

5

6 Instream hydrological variability, encapsulating elements of the entire flow regime such

7 as the daily, seasonal and annual patterns of discharge, the frequency, timing,

8 predictability and duration of extreme flows (high and low), rates of change in

9 discharge, and the magnitude of flows, are widely recognised as key ecological

10 organizers in fluvial ecosystems (Richter et al., 1996; Poff et al., 1997; Hart and Finelli,

11 1999; Bunn and Arthington, 2002). Spatial variation of these characteristics is

12 determined by variations in climate and mediated by basin geology, topography and

13 vegetation (Winter, 2001). These hydrological and environmental factors influence the

14 physical habitat for aquatic and riparian biota determining the conditions for

15 reproduction and recruitment and affecting the availability of trophic resources, refuges

16 during adverse situations and opportunities for dispersal (Naiman et al., 2008).

17 Consequently, flow variability has strong ecological implications which shape the

18 structure and function of riverine ecosystems from the local to regional scales, and from

19 days (ecological effects) to millennia (evolutionary effects) (Lytle and Poff, 2004). It

20 has been hypothesised that sites with similar hydrological characteristics should share

21 similar faunal community composition, traits and ecosystem functioning (Poff and

22 Ward, 1989). Therefore, as Arthington et al. (2006) and Poff et al. (2010) suggested,

23 ecological responses of flow regimes to a given anthropogenic change should be

24 broadly similar in rivers with similar natural flow regimes.

This hypothesis provides a powerful foundation to predict ecological responses to future

27 flow regime changes, constituting the key element of a new holistic framework for 28 developing scientifically-credible regional environmental flows: the "Ecological Limits 29 of Hydrologic Alteration" (ELOHA) (Arthington et al., 2006; Kennard et al., 2010;

30 Poff et al., 2010). Therefore, identifying and quantifying specific relationships between

31 flow regimes and biological communities in undisturbed river ecosystems are essential 32 steps to ensure sustainable river management (Arthington et al., 2006; Jowett and 33 Biggs, 2009). Such relationships have been studied in general at the regional scale, 34 using macroinvertebrates (e.g. Monk et al., 2006; Konrad et al., 2008; Kennen et al., 
1 2010, Armanini et al., 2011), fisheries (e.g Poff and Allan, 1995; Pegg and Pierce, 2 2002; Kennard et al., 2007; Snelder et al., 2009) or multiple taxonomic groups (e. g. 3 Jowett and Duncan, 1990; Clausen and Biggs, 1997). However, the strength and nature 4 of relationships between the flow regime and the biological assemblage vary depending 5 on the geographical region, the floral or faunal group considered and the taxonomic 6 resolution analysed.

8 In some areas, such as Mediterranean-climate regions, organisms have to withstand high 9 intra and interannual hydrological variability, together with frequent natural flow 10 extremes (floods and droughts) (Gasith and Resh, 1999). Species may respond over 11 evolutionary time scales by developing morphological, physiological and/or life-history 12 traits to bear such stresses (Poff et al., 1997; Bonada et al., 2007a; Bonada et al., 13 2007b). Previous studies of Mediterranean streams (e. g. Bonada et al., 2002; Jáimez14 Cuéllar et al., 2002; Vivas et al., 2002; Bonada et al., 2004; Mellado, 2005; Sanchez15 Montoya et al., 2007; Argyroudi et al., 2009) as well as other semiarid areas (e. g. 16 Boulton and Lake, 2008) have highlighted the importance of flow permanence on the 17 composition and structure of macroinvertebrate communities. A progressive 18 replacement of Ephemeroptera, Plecoptera and Trichoptera (EPT) taxa by Odonata, 19 Coleoptera and Heteroptera $(\mathrm{OCH})$ taxa has been reported as flow permanence 20 decreases (Sánchez-Montoya et al., 2007; Argyroudi et al., 2009) or hydrological 21 connectivity is reduced (Bonada et al., 2006); although Diptera have also been associated with river sections with low or no flows and dominate lentic habitats in 23 Southeast Spain (Vivas et al. 2002). Consequently, flow stability and hydrological extremes (especially low flows) are expected to be the most important components of Mediterranean flow regimes shaping instream assemblages, although its relative 26 importance is still unclear.

The aim of this study was to quantify the effect of different flow regimes on macroinvertebrate communities. We utilised a dataset containing stream macroinvertebrate records at family, genus and species level across a semiarid Mediterranean region that encompasses a wide gradient of hydrological regimes 32 (Belmar et al 2011) to test these predictions: (1) Flow stability and minimum flows 33 should be the principal hydrological drivers of macroinvertebrate assemblage 34 composition and richness; (2) an increase in the explanatory power of hydrology should 
1 occur as taxonomic resolution increases; and (3) a replacement of taxa should take place

2 along a hydrological gradient from permanent streams with stable discharges to streams 3 with high flow intermittence and flow variability. In general, a decrease in the 4 percentage of flow sensitive Ephemeroptera, Plecoptera and Trichoptera families should 5 occur as an increase in the percentage of more resilient Odonata, Coleoptera, 6 Heteroptera and Diptera families takes place.

\section{Methods}

9 Study area

10 Located in the Southeast of Spain, the Segura River Basin drainage network, including 11 coastal watercourses draining to the Mediterranean Sea, was selected as the study area. 12 The management area of the Segura River Basin, one of the most arid zones of the 13 Mediterranean region, includes watercourses with highly heterogeneous flow regimes. 14 These water-bodies range from perennial rivers, with low seasonal and interannual flow 15 variability, to highly seasonal ephemeral streams (Belmar et al., 2011). This variability 16 is due to a strong climatic and altitudinal gradient from NW to SE, despite its relatively 17 small size $\left(18870 \mathrm{~km}^{2}\right)$. Climate ranges from wet $(>1000 \mathrm{~mm}$ mean annual 18 precipitation) and cold in the high elevation mountains of the NW (>1000 m.a.s.1.) to 19 semiarid and hot in the SE lowlands (<350 $\mathrm{mm}$ mean annual precipitation). Mean 20 annual temperatures range between 10 and $18{ }^{\circ} \mathrm{C}$ (CHS, 2007). The lithology of the 21 plains is characterised by limestone (karst) and Miocene and Triassic marls, with some small influences of volcanic strata. In contrast, calcites and dolomites dominate the 23 mountainous headwaters. The vegetation is varied and ranges from Mediterranean conifer forests in the NW mountains to arid and semi-arid shrublands in the SE lowlands. This gradient in altitude and climate is coupled with an anthropogenic population density gradient. The river network has low population densities in the 27 forested headwaters, intermediate densities in the agricultural midlands (with major 28 flow regulation) and highly populated cities in the lowlands (Mellado, 2005). 29 Agricultural (52.1\%), forest and semi natural (45.2\%), and artificial (2.1\%) are the 30 dominant landuses in the Segura basin (estimated from Corine Land Cover 2000), 31 making the Segura River Basin one of the most regulated in Europe (Ministerio de 32 Medio Ambiente MMA, 2004). Water resource demands exceed 224\% of that available 33 and only $4 \%$ of runoff reaches the mouth of the river (Zimmer, 2010). This has resulted 34 in over exploitation of the surface waters, an inter-basin transfer from the Tagus River 
1 (a mean of $325 \mathrm{hm}^{3} \mathrm{yr}^{-1}$ ), a mean groundwater extraction of around $478 \mathrm{hm}^{3} /$ year (over $280 \%$ of natural recharge) and a high regulatory capacity of $770 \mathrm{hm}^{3}$ (over $90 \%$ of the 3 natural input) due to 24 dams over $10 \mathrm{~m}$ in height (Grindlay et al., 2009; Grindlay et al., 4 2011). 5

\section{Hydrological data}

7 A drainage network was derived from a $25 \mathrm{~m}$ digital elevation model (DEM) developed 8 by the Instituto Geológico Nacional (IGN) and layers available from the website of the 9 Spanish Ministry of Environment, using the ArcGIS software (v 9.2) and the ArcHydro 10 extension (v 1.2) (ESRI, Redlands, California, U.S.A.). The network comprises sections 11 that link each network junction or node, and each node was associated with its 12 corresponding watershed (derived from the DEM). The minimum watershed area to 13 define a river section was $10 \mathrm{~km}^{2}$, resulting a hydrological network with 390 river 14 sections.

The hydrological classification developed for the Segura River Basin in Belmar et al.

17 (2011) was used to define distinct natural hydrological regimes. This classification was 18 developed using 73 indices based on the "Indicators of Hydrologic Alteration" (IHA) 19 (Mathews and Richter, 2007). These flow indices represent a wide range of ecologically-relevant flow statistics (Richter et al., 1996; Olden and Poff, 2003; Monk et al., 2006; Mathews and Richter, 2007; Monk et al., 2007) and comprise monthly and annual flow statistics including measures of duration of droughts as well as the central tendency and dispersion of flow magnitude (average, low and high flow conditions). Indices related to the frequency, duration and rate of change of high flow events were not used by Belmar et al. (2011) due to the absence of daily flow data. Natural flows were derived from a monthly rainfall-runoff model developed by the Centre for Hydrographic Studies (CEDEX, Ministry of Environment and Public Works, Spain), for the period 1980/81 - 2005/06. The classification of the flow regimes recorded comprised eight flow-regime classes (names are provided throughout to aid interpretation) principally characterised by the magnitude of mean annual flow, the duration of droughts and the interannual variation of flow (Table I). The resulting flow regimes can be placed into four broad hydrological groups: (1) mainstem rivers, with perennial flow thorough the year, low interannual variation and an average annual discharge greater than $10 \mathrm{~m}^{3} / \mathrm{s}$ (class 1 , large rivers) or between 2 and $10 \mathrm{~m}^{3} / \mathrm{s}$ (class 2 , 
1 medium rivers); (2) perennial stable streams, which only difference respect to mainstem 2 rivers is their reduced average discharge, between 0.3 and $2 \mathrm{~m}^{3} / \mathrm{s}$ (class 3 , creeks) or 3 lower than $0.3 \mathrm{~m}^{3} / \mathrm{s}$ (class 4, headwater streams); (3) perennial seasonal streams, which 4 eventually cease flowing (although perennial surface water persists) and with peak 5 discharges in winter (class 5, winter peak flow seasonal streams) or spring (class 6, 6 spring peak flow seasonal streams); and (4) temporary streams, including intermittent 7 streams (class 7), which do not flow for between $20 \%$ and $50 \%$ of the time, and 8 ephemeral streams, that do not experience flow for more than $50 \%$ of the time (class 8 ).

9 Indices and classes were assigned to their corresponding river section.

\section{Macroinvertebrate data}

12 Macroinvertebrate abundance data at family, genus and species level were compiled 13 from the Biodiversidad database (Ecología Acuática research group, Department of 14 Ecology and Hydrology, University of Murcia, Spain). Species data were available for 15 beetles (Coleoptera), which have been recorded in all kinds of water bodies in the 16 region and have been shown to be good indicators of aquatic biodiversity (Bilton et al., 17 2006; Sanchez-Fernandez et al., 2006). Samples had been taken along $100 \mathrm{~m}$ stream 18 transects using a kick-net $(500-1000 \mu \mathrm{m})$ and following the multi-habitat protocol 19 (Jáimez-Cuéllar et al., 2002). Baseline macroinvertebrate samples were collected 20 between 1980 and 2006.

21

22 A minimum of 5 samples per hydrological class were selected, ensuring that they had 23 been collected in freshwater streams (conductivity $<5000 \mu \mathrm{S} \mathrm{cm}^{-1}$ ), above water regulation infrastructures (e.g., dams or weirs) and abstraction areas and in absence of significant evidences of anthropogenic alteration. However, using the criteria above two classes did not have any biological data: large rivers (class 1), due to the absence of 27 reference conditions, and ephemeral streams (class 8), where no sampling had been undertaken due to their frequent dry status.

30 Every sample was collected during the spring or early summer from a different 31 sampling site (Figure 1). This time-period is considered the most representative of the 32 annual macroinvertebrate community composition in Mediterranean streams (Bonada et 33 al., 2009). Each site was paired with the closest downstream node in the drainage 34 network. In order to avoid pseudoreplication, when there was more than one site (and 
1 sample) available for the same node, only the closest to the hydrological node was

2 selected. The final dataset consisted of 35 samples associated with 83 macroinvertebrate

3 families, and 133 genera, and 43 samples associated with 110 Coleoptera species

4 (Appendix A).

5

6 Environmental data

7 Climatic, topographic and geologic variables that were assumed to control hydrological

8 processes (Snelder et al., 2005) were derived from different GIS layers available for the

9 watershed. Average annual precipitation and air temperature were derived from $1 \mathrm{~km}$

10 grid maps created by the Spanish Ministry of Environment by means of interpolation

11 using data from the Spanish weather stations network (Estrela et al., 1999). Drainage

12 area, mean altitude and slope were calculated using the IGN's digital elevation model

13 (DEM). Geology was characterised by the percentage of karst area in each watershed

14 and derived from the "Spain's Map of Karst" 1:1 000000 developed by the Instituto

15 Geológico y Minero de España (IGME) and, indirectly, through water conductivity

16 (recorded for every biological sample). We hypothesised that the karstic surface would

17 control groundwater storage and baseflow (Snelder and Biggs, 2002) and that higher

18 conductivities would reflect the predominance of sedimentary marls that result in flashy

19 hydrographs that reflect precipitation patterns (Bracken et al., 2008).

\section{Data analysis}

22 A Principal Component Factor Analysis (PCFA) (i.e. a Principal Components Analysis 23 (PCA) combined with a Varimax rotation) was used to examine dominant patterns of 24 intercorrelation among the hydrological indices (Belmar et al. 2011) and to identify subsets of indices that describe the major sources of variation while minimizing redundancy (i.e. multicollinearity). The Varimax rotation allows obtaining a clearer 27 pattern of loadings (indices clearly marked by high loadings for some axes and low 28 loadings for others) and, therefore, a better interpretation of the meaning of each axis. 29 The hydrological characteristics of each stream in the network were defined through the 30 corresponding PCFA scores (hydrological components) and hydrological class.

32 Rare taxa (those collected at fewer than 5\% of sampling sites) were removed for 33 multivariate analyses. Abundance data were transformed by means of the Beals 34 smoothing function (Beals, 1984; McCune, 1994) to reduce noise by enhancing the 
1 pattern of joint occurrences. This function is appropriate in the current investigation

2 because the data consist of a large number of small sample units (Peck et al., 1995) and

3 fulfill the requirements established by De Cáceres and Legendre (2008).

4

5 For each taxonomic level analysed, we performed a non-metric multidimensional 6 scaling (NMDS) ordination based on Bray-Curtis distances among the sampling sites.

7 The strength of the correlation between the NMDS axes and the environmental 8 variables, as well as the hydrological components, was plotted as vectors. In addition,

9 the individual variables and components were analyzed using Pearson coefficients.

10 Covarying (redundant) environmental variables were removed for subsequent model

11 development since the primary objective of the research was to determine the most 12 important flow components influencing macroinvertebrate assemblages and not to 13 distinguish the independent effect of hydrological and environmental drivers.

15 Distance based linear models (DistLM) were developed to assess the importance of 16 hydrological components driving taxonomical differences among sites. DistLM 17 calculates a multivariate multiple regression analysis between any symmetric distance 18 matrices, including a permutation test, as described by McArdle and Anderson (2001). 19 The final models were selected following a forward-stepwise procedure. For each 20 taxonomic level, marginal tests determined the variance explained by each flow 21 component and the sequential procedure discarded the variance shared by more than one thereby avoiding the overestimation of their effect on the community.

23

Similarly, generalised linear models (GLM) were employed to determine how 25 hydrological components (independent variables) affected faunal richness patterns. Models were constructed using log-transformed data following a forward-stepwise 27 procedure, assuming a Gaussian error distribution for the dependent variables. These 28 variables were the richness of Coleoptera species, number of macroinvertebrate genera, 29 number of macroinvertebrate families and the ratio EPT/EPTOCHD (defined by the 30 richness of Ephemeroptera, Plecoptera, Trichoptera, Odonata, Coleoptera, Heteroptera 31 and Diptera families). The latter is based on the EPT/EPTOCH ratio, which is used to 32 characterise temporary and lotic-lentic conditions in Mediterranean-climate regions 33 (Bonada et al., 2006). 
1 A non-metric single-factor Analysis of Similarity (ANOSIM) was used to test whether

2 assemblage composition differed among hydrological classes and, therefore, if natural

3 regimes can be used to differentiate distinct groups of invertebrate communities. Global

$4 \mathrm{R}$ indicates if assemblages are randomly grouped (i.e., $\mathrm{R}=0$ ) or not (usually $0<\mathrm{R} \leq 1$,

5 although negative values are possible sensu Clarke (1993)). R pairwise values were also

6 obtained for each pair of classes, indicating whether intra-class similarities were greater

7 than inter-class similarities ( $\mathrm{R}$ value close to 1 ).

9 Indicator taxa were defined for each hydrological class using the Indicator Species 10 analysis (IndVal) of Dufrene \& Legendre (1997). This analysis generates an indicator 11 value index (IV) for each taxon and class, calculated on the basis of the specifity 12 (maximum when a taxon only occurs in one class) and fidelity (maximum when all sites 13 in a class have the taxon) of each taxon to each class.

15 All permutation tests (DistLM, ANOSIM and IndVal) were undertaken using 999 16 permutations. PCFA was undertaken in STATISTICA v 6 (Statsoft, 2001). NMDS and 17 IndVal were conducted using PC-ORD software v 4.42 (McCune and Grace, 2002). 18 ANOSIM and DistLM were undertaken in PRIMER v6 (Clarke and Gorley, 2006). 19 GLM were performed using the R statistical software v 2.12.2 (R Development Core 20 Team, 2008).

21

22 Results

23 Hydrological components

24 The three first PCFA axes were selected to represent the set of hydrological indices 25 since all of them explained greater than $10 \%$ of the variance (46, 28 and 12\%, 26 respectively) and the forth axis only explained an additional $4 \%$. The first axis was 27 positively correlated with mean and maximum monthly flows (Table IIa), representing 28 the flow magnitude component of the IHA. The second axis was negatively correlated 29 with the inter-annual coefficients of variation in monthly flows, the intra-annual 30 coefficient of variation in maximum monthly flows and the percentage of time without 31 flows. These variables characterise the inter- and intra-annual variability of the flow 32 regime and as a result this axis was defined as the flow stability component (Table IIb). 33 The third axis, magnitude of minimum flows, was correlated with all the minimum 34 monthly flows and their average value (Table IIc). 
2 These three hydrological components (PCFA axes) displayed significant positive 3 correlations with mean altitude and precipitation in the watershed, and negative 4 correlations with mean temperature (Table III). In addition, karst surface and slope were 5 positively correlated with flow stability and minimum flows, while drainage area was associated with the magnitude of flow. As anticipated, conductivity displayed a negative

7 association with flow magnitude and stability.

\section{Hydrological components determining assemblage composition}

10 The macroinvertebrate NMDS ordinations for different taxonomic resolutions identified 11 similar patterns (Figure 2). Sites were structured along a flow stability gradient from 12 perennial headwater streams (left side, class 4) to intermittent streams (right side, class 13 7), although some classes were widely dispersed (particularly class 6 - spring peak flow 14 seasonal streams). This gradient was associated with several environmental variables and hydrological components (PCFA axes). Perennial stable streams (classes 3 and 4) were predominately located on karstic rocks and sites in higher altitude areas with steeper slopes, higher flow stability and relatively high minimum flows. In contrast, intermittent streams were associated to low slopes, reduced flow stability and low minimum flows, but higher conductivity and air temperature.

DistLM models indicated that hydrological components accounted for a significant proportion of the variance in the macroinvertebrate community that increased with taxonomic resolution (Table IV): $28 \%$ for families, $30 \%$ for genus and $38 \%$ for Coleoptera species. In all cases, flow stability and minimum flows were the dominant hydrological drivers of taxonomical differences among sites.

\section{Response of taxonomic richness to hydrological components}

28 GLM results showed a moderate effect of hydrological variables on the richness of macroinvertebrate families, genera and species (Table V). However, the model obtained

30 for the EPT/EPTOCHD ratio explained $36 \%$ of the variance using flow magnitude and 31 flow stability as independent variables. Gradual changes to the relative richness of EPT 32 families were observed from perennial to intermittent hydrological classes, decreasing 33 along the flow magnitude gradient, whilst the OCHD families displayed the opposite 34 pattern (Figure 3). 
2 Differences in assemblage composition among hydrological classes

3 The hydrological classes identified supported significantly different invertebrate 4 assemblages at the family (ANOSIM, $\mathrm{R}=0.39$; $P$-value $<0.05$ ), genus (ANOSIM, $\mathrm{R}=$ $5 \quad 0.34 ; P$-value $<0.05$ ) and species taxonomic level (ANOSIM, $\mathrm{R}=0.40 ; P$-value $<0.05$ )

6 (Table VI). Pair-wise comparisons revealed significant assemblage differences at all 7 taxonomic resolutions between the extremes of the hydrological gradient, perennial 8 stable streams (creeks and headwaters, classes 3 and 4 respectively) and intermittent 9 streams (class 7). Differences between creek and medium river communities (class 2) as 10 well as between creeks and perennial seasonal streams with peak flows during the 11 winter (class 5) increased with the taxonomic resolution, except for the genus level. 12 However, intermittent streams and perennial seasonal streams, both with winter (class 13 5) and spring peak flows (class 6), differed at the genus or at the genus and species 14 levels, respectively. No significant differences were found both between creeks and 15 headwater streams or within seasonal streams (winter and spring peak flows) (Table $16 \mathrm{VI})$.

18 The IndVal analyses determined indicator families for medium rivers (class 2), 19 headwater streams (class 4), spring peak flow seasonal streams (class 6) and intermittent 20 streams (class 7) (Table VII). Medium rivers were characterised by Polycentropodidae 21 (Trichoptera) and Potamanthidae (Ephemeroptera). Headwater streams were defined by 22 one Ephemeroptera (Leptophlebiidae), five families of Trichoptera (Limnephilinae and 23 Beraeidae showed slightly higher Indicator Values) and one Crustacea (Astacidae). 24 Spring peak flow seasonal streams were characterised by Syrphidae (Diptera), which 25 presented the highest Indicator Value in the Segura Basin. Intermittent streams were 26 defined by the presence of Coenagrionidae and Libellulidae (Odonata), Pleidae 27 (Heteroptera) and Noteridae and Hydrophilidae (Coleoptera).

29 Indicator genera were found for all classes except creeks (class 3) and winter peak flow 30 seasonal streams (class 5). Medium rivers (class 2) and headwater streams (class 4) 31 were characterised by Ephemeroptera: Habrophlebia and Potamanthus for the former 32 and Epeorus and Rhithrogena for the latter. Headwaters were also characterised by 33 seven Coleoptera genera (Oreodytes, Graptodytes, Esolus, Limnebius, Normandia, 34 Hydrocyphon and Oulimnius), two Trichoptera (Rhyacophila and Sericostoma), one 
1 Crustacea (Austropotamobius) and two Plecoptera (Perla and Isoperla). Spring peak

2 flow seasonal streams (Class 6) were characterised by one genus of Coleoptera

3 (Dytiscus), Hirudinea (Helobdella), Molusca (Pseudamnicola) and Odonata

4 (Platycnemis), with identical indicator values. Intermittent streams (class 7) highlighted

5 the highest number of indicator genera, with the highest Indicator Values for two

6 Diptera (Dasyhelea and Anopheles), two Heteroptera (Heliocorisa and Anisops), two

7 Odonata (Anax and Sympetrum) and two Coleoptera (Enochrus and Berosus).

9 Coleoptera indicator species were detected for all classes except spring peak flow 10 seasonal streams (class 6) (Table VII). Medium rivers (class 2) were primarily 11 characterised by Hydraena manfredjaechi and Normandia nitens; creeks (class 3) by 12 Hydraena exasperata; headwater streams (class 4) by Helophorus alternans; winter 13 peak flow seasonal streams (class 5) by Eretes griseus and Ranthus suturalis; and 14 intermittent streams (class 7) by Ochthebius delgadoi.

\section{Discussion}

17 The importance of hydrological components on macroinvertebrate assemblages

18 The research presented herein supports the general hypothesis that streams with similar

19 flow regimes express greater than random similarity in macroinvertebrate assemblages 20 composition (Resh et al., 1988; Poff, 1996). Our results demonstrate relatively strong 21 relationships between community composition and the flow regimes at different 22 taxonomic levels. The strength of these relationships increased with taxonomic 23 resolution suggesting that the species level data yields the strongest relationships and 24 that, where it is available, it should be used in ecohydrological investigations (Monk et 25 al., 2012). Flow stability and minimum flows were shown to be the principal 26 hydrological drivers/descriptors of the macroinvertebrate community assemblages in the 27 Segura River Basin. Similar results were reported by Chinnayakanehalli et al. (2011) in 28 western USA, where baseflows and seasonality were the main predictors of invertebrate 29 composition. However, these results contrast with studies performed in temperate30 maritime regions where the magnitudes of mean flows or high flows were reported to be 31 the best predictors of macroinvertebrate assemblages (Clausen and Biggs, 1997; Monk 32 et al., 2006; Monk et al., 2008). 
1 Flow stability and minimum flows are major determinants of habitat availability and 2 connectivity that affect aquatic macroinvertebrate assemblages. Flow stability reflects 3 seasonal and interannual patterns of variation, associated with the predictability of flows 4 (Poff, 1996) and the stability of habitat conditions in terms of depth, flow velocity and 5 hydraulic forces (Suen and Herricks, 2009). The variation of stream flow velocity 6 configures stream morphology, water temperature, bed stability and consequently the 7 availability of aquatic habitats for instream organisms (Jowett and Duncan, 1990).

8 Minimum flows represent an extreme of the flow, particularly in the dry season, and 9 reflect the magnitude of seasonal droughts (Smakhtin, 2001). Habitat heterogeneity is 10 reduced under low flow conditions because wetted width, water depth and flow velocity 11 also diminishes (Walters and Post, 2011). In addition, extreme low flows can reduce 12 longitudinal connectivity and increase physical stresses transforming streams into series 13 of isolated pools with higher water temperature and elevated conductivity (Stanley et 14 al., 1997). Consequently, droughts have been recognised as an important part of the 15 natural flow regime in intermittent streams (Boulton, 2003; Lake, 2003; Sheldon and 16 Thoms, 2006, Chase, 2007). Species inhabiting intermittent streams must have 17 physiological, behavioural or life-history adaptations to cope with higher conductivities, 18 predation pressures and habitat isolation, such as short life-histories, generalist feeding, 19 aerial respiration or active aerial dispersal (e.g. Bonada et al., 2007b). Under these 20 conditions, dispersal abilities and distances between or along water bodies have been 21 found to be primary determinants of community composition (McAbendroth et al., 22 2005), because active movement when the riverbed is dry is limited to a small number 23 of taxa such as dytiscid and hydrophilid beetles (Boulton et al., 2006; Larned et al., 24 2010).

Our results indicate a moderately strong relationship between flow regime and faunal 27 richness at the different taxonomic resolutions, weaker than that between flow regime 28 and community composition (especially at species level). Other studies have also 29 reported a moderate effect of minimum flows (Walters and Post, 2011), flow seasonality 30 or the number of days with zero flow (Chinnayakanahalli et al., 2011).

31

32 In Mediterranean regions, ephemeral and intermittent streams are recognised to be 33 significantly less diverse than perennial streams (Bonada et al., 2007b) and to differ in 34 community composition (e.g. Bonada et al., 2006; Argyroudi et al., 2009). Our results 
1 found a strong relationship between flow magnitude, and stability, and the ratio of 2 EPT/EPTOCHD. This supports the findings of Bonada et al. (2006) and Sánchez-

3 Montoya et al. (2007), who reported a decrease in EPT richness as hydrological 4 isolation and the length of the dry period (temporality) increased. EPT taxa in particular 5 tend to occur in riffles, whereas pools support the majority of OCHD taxa (Vivas et al., 6 2002; Oscoz et al., 2011). Therefore, riffle permanence has a strong effect on the 7 structure of benthic assemblages in streams (Feminella, 1996).

9 Biological significance of hydrological classes

10 The six hydrological classes examined in this study indicate distinct macroinvertebrate 11 assemblages at all of the taxonomic resolutions considered. Taxonomic differences were 12 greatest between the classes at both extremes of the flow stability gradient, and are 13 similar to results reported by other studies in the Iberian Peninsula (Sanchez-Montoya et $14 a l ., 2007$ ) and in the Segura Basin (Millan et al., 2006; Diaz et al., 2008; Carbonell et $15 a l ., 2011)$. However, when the other classes were considered, only minor and gradual 16 biological changes along the gradient were detected. Consequently, a simpler 17 classification with four broad hydrological types (Belmar et al. 2011) is more 18 appropriate for management purposes in the Segura River Basin and other semi-arid 19 Mediterranean basins: (1) mainstream rivers (classes 1 and 2), (2) perennial stable 20 streams (classes 3 and 4), (3) perennial seasonal streams (classes 5 and 6) and (4) 21 temporary streams (classes 7 and 8).

22

23 We found a clear agreement between the selection of indicator taxa in this study and 24 those from other studies in the Mediterranean region in Spain (e.g., Bonada et al., 2004; 25 Mellado, 2005; Sanchez-Montoya et al., 2007). Headwater streams were characterised 26 by taxa that inhabit the upper reaches of rivers with colder and oxygen-rich waters, in 27 areas of cobbles and small boulders. These sites supported the greatest presence of 28 Ephemeroptera (Leptophlebiidae) and Trichoptera (e.g. Limnephilinae and Beraidae) 29 families and were also characterised by the presence of typically reophilic 30 Ephemeroptera (Epeorus and Rhitrogena) and Plecoptera (Perla and Isoperla) genera. 31 In general, these taxa are considered to have high oxygen requirements and their 32 presence is associated with good water quality (Jacobsen et al., 2003). Medium rivers 33 were characterised by Ephemeroptera genera, such as Potamanthus and Habrophlebia, 34 typical of reaches of large rivers where low to moderate flow velocities, associated with 
1 gravel and sand substrates, predominate (Puig et al., 1984). Intermittent streams were

2 associated with taxa from shallow standing waters or those with reduced velocities, such

3 as numerous Coleoptera (e.g., Enochrus, Berosus and Noterus), Odonata (e.g., Anax,

4 Sympetrum and Isnchnura) and Heteroptera (e.g., Heliocorisa, Anisops and Sigara),

5 with highly mobile adults (Bilton et al., 2001) and short life-history development times

6 (Velasco et al., 1990; Barahona et al., 2005). The importance of Coleoptera in

7 temporary streams highlighted in this study has also been demonstrated in several

8 previous studies (Picazo et al., 2012).

9

10 Implications to river restoration and conservation

11 Based on the results presented, the magnitude of monthly minimum flows and the inter-

12 and intra-annual natural variation of flows are two key flow components for the

13 definition of environmental flows in Mediterranean basins. Currently, many historically

14 perennial streams have already become intermittent due to excessive abstraction and

15 impoundment, while others exhibit an inverse seasonal pattern due to water release from

16 reservoirs during the summer months (Belmar et al., 2010). Such hydrological

17 modifications could become more intense in the future as a result of climate change

18 (European Environment Agency, 2008), which is expected to intensify supra-seasonal

19 droughts and lead to more anthropogenic water withdrawals. This may lead to the

20 depletion of groundwater in local aquifers and, therefore, flow intermittency in

21 previously perennial streams. Such intermittency could result in significant changes to

22 the faunal community, increasing the risk of local extinctions of drought-sensitive taxa.

23 This effect has already been documented in desert streams (Bogan and Lytle, 2011),

24 where simplified pools composed of the most tolerant and resilient species have been

25 described (sensu Cote and Darling, 2010). Therefore, the conservation and, where

26 appropriate, restoration of natural hydrological variability is crucial for the maintenance

27 of riverine ecosystem integrity (i.e., ecosystem structure and function) (Thoms, 2006;

28 Vaughan et al., 2009).

29

30 Future research should focus on how the degree of hydrological alteration affects 31 aquatic communities and ecosystem functioning. Aquatic macroinvertebrates are ideal 32 candidates for the development of hydro-ecological models to quantify the effects of 33 flow reduction (Castella et al., 1995; Niu and Dudgeon, 2011a; Niu and Dudgeon, 34 2011b). Using the four broad hydrological types stated we will be able to provide a 
1

2

3

4

5

6

7

8

9

10

11

12

1 reference framework in the near future to achieve a more sustainable management of 2 ecohydrological resources in the Segura River Basin and other Mediterranean basins, 3 fulfilling the objectives of ELOHA and EU Water Framework Directive criteria.

4

5 Acknowledgements

6 We wish to thank the University of Murcia and the Fundación Séneca for their financial 7 support to Óscar Belmar and Cayetano Gutiérrez-Cánovas, respectively, by means of 8 pre-doctoral grants; the Euromediterranean Institute of Water for its support to the 9 project "Hydrological classification of the rivers and streams in the Segura basin and 10 associated macroinvertebrate communities"; the Confederación Hidrográfica del 11 Segura for providing the climatic data and the SIMPA model; and the Instituto 12 Geográfico Nacional as well as the Instituto Geológico y Minero de España for the GIS 13 data. 
Table I. Mean and standard deviation of the mean annual flow (MADIS), time with zero flow $\left(\mathrm{D}_{\mathrm{L}}\right)$ and coefficient of variation in annual flows (CV INTER) for the natural flow regime classes defined in the Segura River Basin (Belmar et al. 2011).

\begin{tabular}{lcrrr}
\multicolumn{1}{c}{ Hydrological class } & Number of stream sections & ${\text { MADIS }\left(\mathrm{m}^{3} / \mathrm{s}\right)}_{\mathrm{S}_{\mathrm{L}}(\%)} \mathrm{CV}_{\text {INTER }}$ \\
\hline Class 1: Perennial large size rivers & 17 & $11.30( \pm 0.74)$ & $0.00( \pm 0.00)$ & $0.52( \pm 0.01)$ \\
Class 2: Perennial medium size rivers & 31 & $3.76( \pm 2.26)$ & $0.00( \pm 0.00)$ & $0.50( \pm 0.13)$ \\
Class 3: Perennial stable creeks & 21 & $1.00( \pm 0.45)$ & $0.00( \pm 0.00)$ & $0.32( \pm 0.09)$ \\
Class 4: Perennial stable headwater streams & 43 & $0.18( \pm 0.17)$ & $0.00( \pm 0.00)$ & $0.26( \pm 0.13)$ \\
Class 5: Perennial winter peak flow seasonal streams & 26 & $0.37( \pm 0.09)$ & $2.31( \pm 2.06)$ & $1.39( \pm 0.29)$ \\
Class 6: Perennial spring peak flow seasonal streams & 110 & $0.06( \pm 0.06)$ & $4.46( \pm 6.32)$ & $0.81( \pm 0.30)$ \\
Class 7: Temporary intermittent streams & 101 & $0.04( \pm 0.04)$ & $24.88( \pm 13.15)$ & $1.71( \pm 0.38)$ \\
Class 8: Temporary ephemeral streams & 41 & $0.01( \pm 0.01)$ & $61.90( \pm 20.21)$ & $3.43( \pm 0.84)$ \\
\hline
\end{tabular}


2

3

4

5

6

7

8

9

Table II. Pearson correlation coefficients between the three rotated PCFA axes and the 73 hydrological indices. Coefficients higher than $10.70 \mathrm{l}$ are in bold letter. Horizontal lines separate indices associated to the three flow components represented by the axes: (a) magnitude (average and maximum flows), $1^{\text {st }}$ axis $(46 \%$ of variance); (b) flow stability, $2^{\text {nd }}$ axis ( $28 \%$ of variance); and (c) minimum flows, $3^{\text {rd }}$ axis ( $12 \%$ of variance).

\begin{tabular}{|c|c|c|c|c|c|}
\hline & \multirow[b]{2}{*}{ Variable } & \multirow[b]{2}{*}{ Description } & \multicolumn{3}{|c|}{ PCFA axis } \\
\hline & & & $1^{\text {st }}$ & $2^{\text {nd }}$ & $3^{\text {rd }}$ \\
\hline \multirow[t]{31}{*}{ (a) } & $M_{A} 1$ & Mean monthly flow (October) & 0.98 & 0.13 & 0.02 \\
\hline & $M_{A} 2$ & Mean monthly flow (November) & 0.98 & 0.13 & 0.02 \\
\hline & $M_{A} 3$ & Mean monthly flow (December) & 0.99 & 0.12 & 0.05 \\
\hline & $M_{A} 4$ & Mean monthly flow (January) & 0.98 & 0.14 & 0.04 \\
\hline & $M_{A} 5$ & Mean monthly flow (February) & 0.98 & 0.14 & 0.04 \\
\hline & $M_{A} 6$ & Mean monthly flow (March) & 0.99 & 0.12 & 0.03 \\
\hline & $\mathrm{M}_{\mathrm{A}} 7$ & Mean monthly flow (April) & 0.98 & 0.14 & 0.02 \\
\hline & $M_{A} 8$ & Mean monthly flow (May) & 0.98 & 0.15 & 0.04 \\
\hline & $M_{A} 9$ & Mean monthly flow (June) & 0.98 & 0.15 & 0.03 \\
\hline & $M_{A} 10$ & Mean monthly flow (July) & 0.97 & 0.16 & 0.04 \\
\hline & $M_{A} 11$ & Mean monthly flow (August) & 0.97 & 0.16 & 0.05 \\
\hline & $\mathrm{M}_{\mathrm{A}} 12$ & Mean monthly flow (September) & 0.98 & 0.13 & 0.02 \\
\hline & $M_{A} 16$ & Mean annual flow divided by catchment area & 0.18 & 0.50 & 0.35 \\
\hline & MEDDIS/A & Median annual discharge divided by catchment & 0.22 & 0.52 & 0.35 \\
\hline & $M_{H} 1$ & Mean of the maximum monthly flows (October) & 0.96 & 0.08 & 0.01 \\
\hline & $\mathrm{M}_{\mathrm{H}} 2$ & Mean of the maximum monthly flows (November) & 0.96 & 0.06 & 0.07 \\
\hline & $\mathrm{M}_{\mathrm{H}} 3$ & Mean of the maximum monthly flows (December) & 0.91 & 0.00 & 0.05 \\
\hline & $\mathrm{M}_{\mathrm{H}} 4$ & Mean of the maximum monthly flows (January) & 0.97 & 0.14 & 0.08 \\
\hline & $\mathrm{M}_{\mathrm{H}} 5$ & Mean of the maximum monthly flows (February) & 0.97 & 0.15 & 0.11 \\
\hline & $M_{H} 6$ & Mean of the maximum monthly flows (March) & 0.94 & 0.03 & 0.02 \\
\hline & $M_{H} 7$ & Mean of the maximum monthly flows (April) & 0.98 & 0.10 & 0.04 \\
\hline & $\mathrm{M}_{\mathrm{H}} 8$ & Mean of the maximum monthly flows (May) & 0.98 & 0.15 & 0.08 \\
\hline & $\mathrm{M}_{\mathrm{H}} 9$ & Mean of the maximum monthly flows (June) & 0.98 & 0.13 & 0.00 \\
\hline & $M_{H} 10$ & Mean of the maximum monthly flows (July) & 0.98 & 0.13 & -0.03 \\
\hline & $M_{H} 11$ & Mean of the maximum monthly flows (August) & 0.98 & 0.13 & -0.03 \\
\hline & $M_{H} 12$ & Mean of the maximum monthly flows (September) & 0.95 & 0.05 & -0.04 \\
\hline & $M_{H} 13$ & Mean of the mean maximum flows for all months & 0.98 & 0.08 & 0.04 \\
\hline & MADIS & Mean annual flow for all years & 0.98 & 0.14 & 0.03 \\
\hline & RANGE & Maximum annual discharge minus $m$ & 0.98 & 0.06 & -0.05 \\
\hline & Q1 & Percentile flow with the annual dischar & 0.99 & 0.09 & 0.01 \\
\hline & Q50 & Median annual flow for all years & 0.97 & 0.14 & 0.03 \\
\hline \multirow[t]{29}{*}{ (b) } & $\mathrm{CV}_{\mathrm{A}}{ }^{1}$ & Coefficient of variation (October) & -0.08 & -0.83 & -0.30 \\
\hline & $\mathrm{CV}_{\mathrm{A}} 2$ & Coefficient of variation (November) & -0.12 & -0.86 & -0.15 \\
\hline & $\mathrm{CV}_{\mathrm{A}} 3$ & Coefficient of variation (December) & -0.09 & -0.84 & -0.19 \\
\hline & $\mathrm{CV}_{\mathrm{A}} 4$ & Coefficient of variation (January) & -0.19 & -0.88 & -0.21 \\
\hline & $\mathrm{CV}_{\mathrm{A}} 5$ & Coefficient of variation (February) & -0.21 & -0.89 & -0.17 \\
\hline & $\mathrm{CV}_{\mathrm{A}} 6$ & Coefficient of variation (March) & -0.19 & -0.81 & -0.25 \\
\hline & $\mathrm{CV}_{\mathrm{A}} 7$ & Coefficient of variation (April) & -0.26 & -0.90 & -0.20 \\
\hline & $\mathrm{CV}_{\mathrm{A}} 8$ & Coefficient of variation (May) & -0.02 & -0.91 & -0.19 \\
\hline & $\mathrm{CV}_{\mathrm{A}} 9$ & Coefficient of variation (June) & 0.02 & -0.83 & -0.35 \\
\hline & $\mathrm{CV}_{\mathrm{A}} 10$ & Coefficient of variation (July) & 0.09 & -0.82 & -0.37 \\
\hline & $\mathrm{CV}_{\mathrm{A}} 11$ & Coefficient of variation (August) & 0.09 & -0.84 & -0.36 \\
\hline & $\mathrm{CV}_{\mathrm{A}} 12$ & Coefficient of variation (September) & -0.03 & -0.81 & -0.34 \\
\hline & $M_{A} 13$ & Range divided by median monthly flow & -0.06 & -0.90 & -0.03 \\
\hline & $\mathrm{M}_{\mathrm{A}} 14$ & Interquartile divided by median monthly flow & 0.09 & -0.80 & 0.05 \\
\hline & $\mathrm{CV}_{\text {INTRA }}$ & Coefficient of variation in mean monthly flows & 0.02 & -0.90 & -0.03 \\
\hline & $\mathrm{M}_{\mathrm{A}} 15$ & Mean minus median monthly flow divided by median monthly flow & -0.15 & -0.73 & 0.06 \\
\hline & $\mathrm{M}_{\mathrm{A}} 17$ & Range divided by median annual flow & -0.22 & -0.93 & -0.10 \\
\hline & $\mathrm{M}_{\mathrm{A}} 18$ & Interquartile divided by median annual flow & -0.17 & -0.83 & -0.05 \\
\hline & $M_{A} 19$ & Mean minus median annual flow divided by median annual flow & -0.17 & -0.84 & 0.03 \\
\hline & $\mathrm{CV}_{\mathrm{H}}$ & Coefficient of variation in mean maximum monthly flows & -0.27 & -0.79 & -0.08 \\
\hline & $D_{L}$ & Percentage of months with zero flow & -0.38 & -0.75 & -0.24 \\
\hline & $\mathrm{CV}_{\text {INTER }}$ & Coefficient of variation in annual flows for all years & -0.21 & -0.92 & -0.25 \\
\hline & Q5/Q50 & Q5 divided median monthly flow & -0.23 & -0.88 & -0.08 \\
\hline & Q10/Q50 & Q10 divided median monthly flow & -0.21 & -0.87 & -0.06 \\
\hline & STDEV & Standard deviation of annual discharge & 0.99 & 0.07 & -0.09 \\
\hline & AMAX/Q50 & Maximum annual discharge divided by Q50 & -0.23 & -0.92 & -0.08 \\
\hline & AMIN/Q50 & Minimum annual discharge divided by Q50 & -0.25 & 0.63 & 0.42 \\
\hline & $I_{H}$ & Q5 divided mean monthly flow & 0.08 & -0.04 & -0.27 \\
\hline & $\mathrm{I}_{\mathrm{L}}$ & Q95 divided mean monthly flow & -0.26 & 0.60 & 0.48 \\
\hline \multirow[t]{13}{*}{ (c) } & $\frac{M_{L}}{\mathrm{M}}$ & Mean minimum monthly flow (October) & 0.02 & 0.19 & 0.92 \\
\hline & $M_{L} 2$ & Mean minimum monthly flow (November) & 0.04 & 0.19 & 0.92 \\
\hline & $M_{L} 3$ & Mean minimum monthly flow (December) & 0.03 & 0.19 & 0.92 \\
\hline & $M_{\llcorner} 4$ & Mean minimum monthly flow (January) & 0.11 & 0.20 & 0.77 \\
\hline & $\mathrm{M}_{\mathrm{L}} 5$ & Mean minimum monthly flow (February) & 0.08 & 0.18 & 0.88 \\
\hline & $M_{L} 6$ & Mean minimum monthly flow (March) & 0.04 & 0.18 & 0.93 \\
\hline & $\mathrm{M}_{\mathrm{L}} 7$ & Mean minimum monthly flow (April) & 0.10 & 0.23 & 0.78 \\
\hline & $M_{L} 8$ & Mean minimum monthly flow (May) & 0.03 & 0.17 & 0.93 \\
\hline & $\mathrm{M} \mathrm{L} 9$ & Mean minimum monthly flow (June) & 0.00 & 0.17 & 0.90 \\
\hline & $M_{\llcorner} 10$ & Mean minimum monthly flow (July) & 0.01 & 0.17 & 0.90 \\
\hline & $M_{\llcorner} 11$ & Mean minimum monthly flow (August) & 0.04 & 0.16 & 0.89 \\
\hline & $M_{L} 12$ & Mean minimum monthly flow (September) & 0.05 & 0.16 & 0.88 \\
\hline & $M_{L} 13$ & Mean of the mean minimum flows for all months & 0.06 & 0.20 & 0.96 \\
\hline
\end{tabular}


Table III. Pearson correlation coefficients between environmental variables and hydrological components (PCFA axes). Significant correlations $(\mathrm{p}<0.05)$ are in bold letter.

\begin{tabular}{lccc} 
Environmental variable & Flow magnitude & Flow stability & Minimum flows \\
\hline Mean precipitation $(\mathrm{mm})$ & $\mathbf{0 . 2 6}$ & $\mathbf{0 . 6 4}$ & $\mathbf{0 . 3 9}$ \\
Conductivity $\left(\mu \mathrm{S} / \mathrm{cm}^{2}\right)$ & $-\mathbf{0 . 2 8}$ & $-\mathbf{0 . 5 4}$ & -0.21 \\
Mean altitude $(\mathrm{m})$ & $\mathbf{0 . 3 4}$ & $\mathbf{0 . 6 4}$ & $\mathbf{0 . 3 4}$ \\
Mean slope $(\stackrel{\circ}{)}$ & 0.24 & $\mathbf{0 . 3 7}$ & $\mathbf{0 . 2 7}$ \\
Karst surface $(\%)$ & 0.21 & $\mathbf{0 . 3 6}$ & $\mathbf{0 . 3 7}$ \\
Mean temperature $(\stackrel{\circ}{\mathrm{C}})$ & $-\mathbf{0 . 3 7}$ & $\mathbf{- 0 . 5 7}$ & $-\mathbf{0 . 2 7}$ \\
Drainage area $\left(\mathrm{km}^{2}\right)$ & $\mathbf{0 . 8 3}$ & -0.16 & -0.14 \\
\hline
\end{tabular}

16

17 
Table IV. Results of the DistLM analyses for each taxonomic level. Significance levels are indicated with asterisks $(*: \mathrm{p} \leq 0.05 ; * *: \mathrm{p} \leq 0.01 ; * * *$ : $\mathrm{p} \leq 0.001)$.

\begin{tabular}{|c|c|c|c|c|c|c|}
\hline \multirow[b]{2}{*}{ Hydrological component } & \multicolumn{2}{|c|}{ Macroinvertebrate families } & \multicolumn{2}{|c|}{ Macroinvertebrate genera } & \multicolumn{2}{|c|}{ Coleoptera species } \\
\hline & Marginal (\%) & Sequential (\%) & Marginal (\%) & Sequential (\%) & Marginal (\%) & Sequential (\%) \\
\hline Flow magnitude & 7 & $6^{*}$ & 6 & 5 & 4 & $3^{*}$ \\
\hline Flow stability & $12^{\star \star \star}$ & $9^{* *}$ & $24^{\star \star \star}$ & $24^{\star * *}$ & $27^{\star \star \star}$ & $27^{* \star \star}$ \\
\hline Minimum flows & $13^{\star *}$ & $13^{\star * *}$ & $11^{* *}$ & $6^{*}$ & $16^{\star * \star}$ & $8^{\star * *}$ \\
\hline Total (\%) & & 28 & & 30 & & 38 \\
\hline
\end{tabular}


Table V. GLM analyses for the different dependent variables, based on richness. Significance levels are indicated with asterisks $(*: p \leq 0.05 ; * *: p \leq 0.01 ; * * *: p \leq 0.001)$.

\begin{tabular}{lcc} 
Dependent variable & Variance explained (\%) & Explanatory hydrological components \\
\hline EPT/EPTOCHD & 36 & Flow magnitude $^{\star \star}$, flow stability $^{\star}$ \\
Macroinvertebrate families & 21 & Minimum flows \\
Macroinvertebrate genera & 24 & Minimum flows \\
Coleoptera species & 17 & Minimum flows \\
\hline
\end{tabular}


Table VI. Results of ANOSIM analyses. Significance levels are indicated with asterisks $(*: \mathrm{p} \leq 0.05 ; * *: \mathrm{p} \leq 0.01 ; * * *: \mathrm{p} \leq 0.001)$.

\begin{tabular}{|c|c|c|c|}
\hline Classes & Macroinv. families & Macroinv. genera & Coleop. species \\
\hline 2,5 & 0.22 & 0.15 & $0.50^{\star *}$ \\
\hline 2,7 & $0.59^{*}$ & $0.62^{*}$ & $0.49^{\star *}$ \\
\hline 3,2 & $0.26^{*}$ & 0.06 & $0.56^{\star *}$ \\
\hline 3,5 & $0.25^{\star}$ & 0.20 & $0.76^{\star \star \star}$ \\
\hline 3,6 & $0.49^{\star *}$ & $0.30^{*}$ & 0.05 \\
\hline 3,7 & $0.50^{\star *}$ & $0.53^{\star *}$ & $0.86^{* \star *}$ \\
\hline 4,2 & $0.85^{\star \star}$ & $0.67^{\star \star}$ & $0.37^{\star *}$ \\
\hline 4,3 & 0.00 & -0.02 & -0.09 \\
\hline 4,5 & $0.81^{\star \star}$ & $0.80^{\star \star}$ & $0.66^{\star \star \star}$ \\
\hline 4,6 & $0.53^{\star \star}$ & $0.77^{\star \star}$ & 0.09 \\
\hline 4,7 & $0.88^{\star \star}$ & $0.86^{\star \star}$ & $0.77^{\star \star \star}$ \\
\hline 5,7 & 0.29 & $0.42^{*}$ & 0.17 \\
\hline 6,2 & $0.27^{\star \star}$ & $0.33^{\star *}$ & -0.01 \\
\hline 6,5 & 0.12 & 0.02 & 0.16 \\
\hline 6,7 & 0.09 & $0.44^{*}$ & $0.38^{* *}$ \\
\hline Global R & $0.39^{\star \star \star}$ & $0.34^{\star \star \star}$ & $0.40^{\star \star \star}$ \\
\hline
\end{tabular}

Class 2: Perennial medium rivers Class 3: Perennial stable creeks Class 4: Perennial stable headwater streams Class 5: Perennial winter peak flow seasonal streams Class 6: Perennial spring peak flow seasonal streams Class 7: Temporary intermittent streams 
Table VII. Indicator taxa (IV $\geq 25 \& \mathrm{p} \leq 0.05)$ for each hydrological class and taxonomic level.

\begin{tabular}{|c|c|c|c|c|c|c|}
\hline Hydrological class & Macroinvertebrate families & IV (\%) & Macroinvertebrate genera & IV & Coleoptera species & IV (\%) \\
\hline \multirow{6}{*}{$\begin{array}{l}\text { 2. Perennial medium } \\
\text { rivers }\end{array}$} & Polycentropodidae & 31 & Habrophlebia & 28 & Hydraena manfredjaechi & 47 \\
\hline & Potamanthidae & 27 & Potamanthus & 27 & Normandia nitens & 47 \\
\hline & & & & & Limnius intermedius & 44 \\
\hline & & & & & Ochthebius difficilis & 34 \\
\hline & & & & & Limnius opacus & 28 \\
\hline & & & & & Pomatinus substriatus & 25 \\
\hline \multirow{14}{*}{$\begin{array}{l}\text { 3. Perennial stable } \\
\text { creeks }\end{array}$} & & & & & Hydraena exasperata & 55 \\
\hline & & & & & Ilybius meridionalis & 50 \\
\hline & & & & & Ochthebius bellieri & 46 \\
\hline & & & & & Limnius volckmari & 34 \\
\hline & & & & & Agabus brunneus & 32 \\
\hline & & & & & Hydroporus marginatus & 30 \\
\hline & & & & & Ochthebius bonnairei & 30 \\
\hline & & & & & Anacaena bipustulata & 29 \\
\hline & & & & & Deronectes moestus & 29 \\
\hline & & & & & Hydraena carbonaria & 29 \\
\hline & & & & & Hydraena capta & 27 \\
\hline & & & & & Hydraena rufipennis & 26 \\
\hline & & & & & Stictonectes epipleuricus & 26 \\
\hline & & & & & Agabus didymus & 25 \\
\hline \multirow{14}{*}{$\begin{array}{l}\text { 4. Perennial stable } \\
\text { headwater streams }\end{array}$} & Leptophlebiidae & 41 & Oreodytes & 45 & Helophorus alternans & 29 \\
\hline & Limnephilinae & 29 & Epeorus & 35 & Helophorus brevipalpis & 28 \\
\hline & Beraeidae & 29 & Rhyacophila & 31 & Laccobius obscuratus & 28 \\
\hline & Brachycentridae & 28 & Graptodytes & 30 & Hydroporus tessellatus & 26 \\
\hline & Rhyacophilidae & 27 & Austropotamobius & 30 & Limnebius cordobanus & 26 \\
\hline & Sericostomatidae & 26 & Esolus & 29 & & \\
\hline & Astacidae & 26 & Sericostoma & 29 & & \\
\hline & & & Limnebius & 28 & & \\
\hline & & & Normandia & 27 & & \\
\hline & & & Hydrocyphon & 27 & & \\
\hline & & & Rhithrogena & 27 & & \\
\hline & & & Oulimnius & 25 & & \\
\hline & & & Perla & 25 & & \\
\hline & & & Isoperla & 25 & & \\
\hline \multirow{8}{*}{$\begin{array}{l}\text { 5. Perennial winter peak } \\
\text { flow seasonal streams }\end{array}$} & & & & & Eretes griseus & 76 \\
\hline & & & & & Rhantus suturalis & 76 \\
\hline & & & & & Hydrochus nooreinus & 52 \\
\hline & & & & & Stictotarsus duodecimpustulatus & 52 \\
\hline & & & & & Berosus hispanicus & 34 \\
\hline & & & & & Hydrophilus pistaceus & 32 \\
\hline & & & & & Laccobius moraguesi & 31 \\
\hline & & & & & Agabus ramblae & 29 \\
\hline \multirow{4}{*}{$\begin{array}{l}\text { 6. Perennial spring peak } \\
\text { flow seasonal streams }\end{array}$} & Syrphidae & 85 & Dytiscus & 35 & & \\
\hline & & & Helobdella & 35 & & \\
\hline & & & Pseudamnicola & 35 & & \\
\hline & & & Platycnemis & 35 & & \\
\hline \multirow{29}{*}{$\begin{array}{l}\text { 7. Temporary intermittent } \\
\text { streams }\end{array}$} & Noteridae & 35 & Dasyhelea & 63 & Ochthebius delgadoi & 42 \\
\hline & Pleidae & 35 & Anopheles & 63 & Enochrus politus & 38 \\
\hline & Coenagrionidae & 30 & Heliocorisa & 63 & Helophorus fulgidicollis & 38 \\
\hline & Libellulidae & 28 & Anisops & 63 & Laccophilus minutus & 38 \\
\hline & Hydrophilidae & 26 & Anax & 52 & Ochthebius auropallens & 38 \\
\hline & & & Enochrus & 48 & Ochthebius grandipennis & 38 \\
\hline & & & Sympetrum & 48 & Ochthebius viridis fallaciosus & 38 \\
\hline & & & Berosus & 45 & Ochthebius jaimei & 35 \\
\hline & & & Sigara & 45 & Helochares lividus & 27 \\
\hline & & & Plea & 45 & & \\
\hline & & & Ischnura & 45 & & \\
\hline & & & Noterus & 42 & & \\
\hline & & & Potamopyrgus & 42 & & \\
\hline & & & Cercion & 42 & & \\
\hline & & & Libellula & 42 & & \\
\hline & & & Helochares & 41 & & \\
\hline & & & Bidessus & 40 & & \\
\hline & & & Procambarus & 40 & & \\
\hline & & & Limnophora & 40 & & \\
\hline & & & Tipula & 40 & & \\
\hline & & & Microvelia & 40 & & \\
\hline & & & Agabus & 36 & & \\
\hline & & & Dryops & 32 & & \\
\hline & & & Laccobius & 32 & & \\
\hline & & & Orthetrum & 32 & & \\
\hline & & & Gerris & 30 & & \\
\hline & & & Nebrioporus & 27 & & \\
\hline & & & Cloeon & 27 & & \\
\hline & & & Micronecta & 25 & & \\
\hline
\end{tabular}


2

\section{Appendix A. Taxa collected in the Segura Basin grouped by taxonomic order.}

\begin{tabular}{|c|c|}
\hline Hirudinea & Oreodytes \\
\hline Erpobdellidae & Stictonectes \\
\hline Dina & Stictonectes epipleuricus (Seidlitz, 1887) \\
\hline Glossiphoniidae & Stictonectes optatus (Seidlitz, 1887) \\
\hline Helobdella & Yola \\
\hline Mollusca & Yola bicarinata (Latreille, 1804) \\
\hline Ancylidae & Elmidae \\
\hline Ancylus & Elmis \\
\hline Ferrissia & Elmis aenea (Müller, 1806) \\
\hline Hydrobiidae & Elmis maugetii maugetii Latreille, 1798 \\
\hline Mercuria & Elmis rioloides (Kuwert, 1890) \\
\hline Potamopyrgus & Esolus \\
\hline Pseudamnicola & Esolus parallelepipedus (Müller, 1806) \\
\hline Lymnaeidae & Limnius \\
\hline Lymnaea & Limnius intermedius Fairmaire, 1881 \\
\hline Melanopsidae & Limnius opacus Müller, 1806 \\
\hline Melanopsis & Limnius volckmari (Panzer, 1793) \\
\hline Physidae & Normandia \\
\hline Physella & Normandia nitens (Müller, 1817) \\
\hline Planorbidae & Normandia sodalis (Erichson, 1847) \\
\hline Gyraulus & Oulimnius \\
\hline Planorbarius & Oulimnius troglodytes (Gyllenhal, 1827) \\
\hline Sphaeriidae & Oulimnius tuberculatus perezi Sharp, 1872 \\
\hline Pisidium & Potamophilus \\
\hline Crustacea & Riolus \\
\hline Astacidae & Riolus cupreus (Müller, 1806) \\
\hline Austropotamobius & Riolus illiesi Steffan, 1958 \\
\hline Atyiidae & Gyrinidae \\
\hline$\overline{\text { Atyaephyra }}$ & $\overline{\text { Aulonogyrus }}$ \\
\hline Cambaridae & Aulonogyrus striatus (Fabricius, 1792) \\
\hline Procambarus & Gyrinus \\
\hline Gammaridae & Gyrinus dejeani Brullé, 1832 \\
\hline Echinogammarus & Orectochilus \\
\hline Coleoptera & Orectochilus villosus (Müller, 1776) \\
\hline Dryopidae & Haliplidae \\
\hline Dryops & Peltodytes rotundatus (Aubé, 1836) \\
\hline Dryops gracilis (Karsch, 1881) & Haliplus \\
\hline Dryops sulcipennis (Costa, 1883) & Haliplus lineatocollis (Marsham, 1802) \\
\hline Pomatinus & Haliplus mucronatus Stephens, 1832 \\
\hline Pomatinus substriatus (Müller, 1806) & Helophoridae \\
\hline Dytiscidae & Helophorus \\
\hline Eretes griseus Motschulsky 1849 & Helophorus alternans Gené, 1836 \\
\hline Hygrotus confluens (Fabricius, 1787) & Helophorus brevipalpis Bedel, 1881 \\
\hline Hyphydrus aubei Ganglbauer, 1892 & Helophorus fulgidicollis Motschuslky, 1860 \\
\hline Mybius meridionalis Aubé, 1836 & Helophorus occidentalis Angus, 1983 \\
\hline Meladema coriacea Castelnau, 1834 & Helophorus nubilus Fabricius, 1776 \\
\hline Rhantus suturalis (McLeay, 1825) & Helophorus seidlitzii Kuwert, 1885 \\
\hline Stictotarsus duodecimpustulatus (Fabricius, 1792) & Hydraenidae \\
\hline Agabus & Hydraena \\
\hline Agabus biguttatus (Olivier, 1795) & Hydraena capta Orchymont, 1936 \\
\hline Agabus bipustulatus (Linnaeus, 1767) & Hydraena carbonaria Kiesenwetter, 1849 \\
\hline Agabus brunneus (Fabricius, 1798) & Hydraena exasperata Orchymont, 1935 \\
\hline Agabus didymus (Olivier, 1795) & Hydraena hernandoi Fresneda \& Lagar, 1990 \\
\hline Agabus nebulosus (Forster, 1771) & Hydraena manfredjaechi Delgado \& Soler, 1991 \\
\hline Agabus nitidus (Fabricius, 1801 & Hydraena pygmaea Waterhouse, 1833 \\
\hline Agabus paludosus (Fabricius, 1801) & Hydraena quilisi Lagar, Fresneda \& Hernando, 1987 \\
\hline Agabus ramblae Millán \& Ribera, 2001 & Hydraena rufipennis Boscá Berga, 1932 \\
\hline Bidessus & Hydraena servilia Orchymont, 1936 \\
\hline Bidessus minutissimus (Germar, 1824) & Limnebius \\
\hline Deronectes & Limnebius cordobanus Orchymont, 1938 \\
\hline Deronectes depressicollis (Rosenhauer, 1856) & Limnebius maurus Balfour-Browne, 1978 \\
\hline Deronectes fairmairei (Leprieur, 1876) & Limnebius oblongus Rey, 1883 \\
\hline Deronectes hispanicus (Rosenhauer, 1856) & Ochthebius \\
\hline Deronectes moestus Leprieur, 1876 & Ochthebius auropallens Fairmaire, 1879 \\
\hline Dytiscus & Ochthebius bellieri Kuwert, 1887 \\
\hline Graptodytes & Ochthebius bonnairei Guillebau, 1896 \\
\hline Graptodytes fractus (Sharp, 1880-82) & Ochthebius delgadoi Jäch, 1994 \\
\hline Graptodytes ignotus (Mulsant, 1861) & Ochthebius difficilis Mulsant, 1844 \\
\hline Graptodytes varius (Aubé, 1836) & Ochthebius dilatatus Stephens, 1829 \\
\hline Hydroglyphus & Ochthebius (Enicocerus) exsculptus Germar, 1824 \\
\hline Hydroglyphus geminus (Fabricius, 1792) & Ochthebius grandipennis Fairmaire, 1879 \\
\hline Hydroglyphus signatellus (Klug, 1834) & Ochthebius jaimei Delgado \& Jäch, 2007 \\
\hline Hydroporus & Ochthebius quadrifoveolatus Wollaston, 1854 \\
\hline Hydroporus discretus Fairmaire, 1859 & Ochthebius tudmirensis Jäch, 1997 \\
\hline Hydroporus lucasi Reiche, 1866 & Ochthebius viridis fallaciosus Ganglbauer, 1901 \\
\hline Hydroporus marginatus (Duftschmid, 1805) & Hydrochidae \\
\hline Hydroporus nigrita (Fabricius, 1792) & Hydrochus \\
\hline Hydroporus pubescens (Gyllenhal, 1808) & Hydrochus grandicollis Kiesenwetter, 1870 \\
\hline $\begin{array}{l}\text { Hydroporus tessellatus Drapiez, } 1819 \\
\text { Laccophilus }\end{array}$ & $\begin{array}{l}\text { Hydrochus nooreinus Henegouven \& Sáinz-Cantero, } 1992 \\
\text { Hydrophilidae }\end{array}$ \\
\hline Laccophilus hyalinus (De Geer, 1774) & Anacaena bipustulata (Marsham, 1802) \\
\hline Laccophilus minutus (Linnaeus, 1758) & Anacaena globulus (Paykull, 1798) \\
\hline Nebrioporus & Anacaena lutescens (Stephens, 1829) \\
\hline Nebrioporus bucheti cazorlensis (Lagar, Fresneda \& Hernando, 1987) & Coelostoma hispanicum (Küster, 1848) \\
\hline Nebrioporus clarki (Wollaston, 1862) & Hydrophilus pistaceus (Castelnau, 1840) \\
\hline
\end{tabular}


Appendix A (cont.).

Berosus

Berosus hispanicus Küster, 1847

Enochrus

Enochrus ater (Kuwert, 1888)

Enochrus politus Küster, 1849

Helochares

Helochares lividus (Forster, 1771)

Laccobius

Laccobius bipunctatus (Fabricius, 1775)

Laccobius hispanicus Gentili, 1974

Laccobius gracillis gracillis Motschulsky, 1849

Laccobius moraguesi Régimbart, 1898

Laccobius neapolitanus Rottenberg, 1874

Laccobius obscuratus Rottenberg, 1874

Laccobius sinuatus Motschulsky, 1849

Laccobius ytenensis Sharp, 1910

Noteridae

Noterus

Noterus laevis Sturm, 1834

Scirtidae

Cyphon

Elodes

Hydrocyphon

Diptera

Anthomyiidae

Limnophora

Athericidae

Atrichops

Ibisia

Ceratopogonidae

Dasyhelea

Chironomidae

Corynoneura

Tanytarsini

Culicidae

Anopheles

Diamesinae

Dixidae

Empididae

Ephydridae

Hemerodromiinae

Limoniidae

Pseudolimnophila

Orthocladiinae

Simuliidae

Stratiomyidae

Oxycera

Syrphidae

Tabanidae

Tabanus

Tanypodinae

Tipulidae

Tipula

Ephemeroptera

Baetidae

Baetis

Centroptilum

Cloeon

Procloeon

Caenidae

Caenis

Ephemerellidae

Ephemerella

Serratella

Torleya

Ephemeridae

Ephemera

Heptageniidae

Ecdyonurus

Epeorus

Rhithrogena

Leptophlebiidae

Habroleptoides

Habrophlebia

Paraleptophlebia

Polymirtacidae

Ephoron

Potamantidae

Potamanthus

Hemiptera

Aphelocheiridae

Aphelocheirus

Corixidae

Heliocorisa

Micronecta

Sigara

Gerridae

Gerris

Hydrometridae

Hydrometra

Naucoridae

Nepida

Notonectidae

Anisops

Notonecta

Pleidae

Plea

Veliidae

Microvelia

Velia

Odonata

Aeshnidae

Anax

Boyeria

Calopterigydae

Calopteryx

Coenagrionidae

Cercion

Ischnura

Pyrrhosoma

Cordulegastridae

Cordulegaster

Gomphidae

Gomphus

Onychogomphus

Libellulidae

Libellula

Orthetrum

Sympetrum

Platycnemididae

Platycnemis

Plecoptera

Leuctridae

euctra

Nemouridae

Nemoura

Protonemura

Perlidae

Dinocras

Eoperla

Perla

Perlodidae

Isoperla

Trichoptera

Beraeidae

Brachycentridae

Micrasema

Drusinae

Hydropsychidae

Cheumatopsyche

Hydropsyche

Hydroptilidae

Agraylea

Hydroptila

Lepidostomatidae

Lasiocephala

Leptoceridae

Athripsodes

Limnephilidae

Allogamus

Halesus

Stenophylax

Limnephilinae

Polycentropodidae

Psychomyiidae

Metalype

Tinodes

Rhyacophilidae

Rhyacophila

Sericostomatidae

Sericostoma 
Argyroudi A, Chatzinikolaou Y, Poirazidis K, Lazaridou M. 2009. Do intermittent and ephemeral Mediterranean rivers belong to the same river type? Aquatic Ecology 43:465476.

Armanini DG, Monk WA, Tenenbaum DE, Peters DL, Baird DJ. 2011. Influence of runoff regime type on a macroinvertebrate-based flow index in rivers of British Columbia (Canada). Ecohydrology. DOI: 10.1002/eco.234.

Arthington AH, Bunn SE, Poff NL, Naiman RJ. 2006. The challenge of providing environmental flow rules to sustain river ecosystems. Ecological Applications 16:13111318.

Barahona J, Millan A, Velasco J. 2005. Population dynamics, growth and production of Sigara selecta (Fieber, 1848) (Hemiptera, Corixidae) in a Mediterranean hypersaline stream. Freshwater Biology 50:2101-2113.

Beals EW. 1984. Bray-Curtis ordination: an effective strategy for analysis of multivariate ecological data. Advances in Ecological Research 14:1-55.

Belmar O, Velasco J, Martinez-Capel F. 2011. Hydrological classification of natural flow regimes to support environmental flow assessments in intensively regulated Mediterranean rivers, Segura River basin (Spain). Environmental Management 47:9921004.

Belmar O, Velasco J, Martinez-Capel F, Marin AA. 2010. Natural flow regime, degre of alteration and environmental flows in the Mula stream (Segura River basin, SE Spain). Limnetica 29:353-368.

Bilton DT, Freeland JR, Okamura B. 2001. Dispersal in freshwater invertebrates. Annual Review of Ecology and Systematics 32:159-181.

Bilton DT, McAbendroth L, Bedford A, Ramsay PM. 2006. How wide to cast the net? Cross-taxon congruence of species richness, community similarity and indicator taxa in ponds. Freshwater Biology 51:578-590.

Bogan MT, Lytle DA. 2011. Severe drought drives novel community trajectories in desert stream pools. Freshwater Biology 56:2070-2081.

Bonada N, Doledec S, Statzner B. 2007a. Taxonomic and biological trait differences of stream macroinvertebrate communities between mediterranean and temperate regions: implications for future climatic scenarios. Global Change Biology 13:1658-1671.

Bonada N, Murria C, Zamora-Munoz C, El Alami M, Poquet JM, Punti T, Moreno JL, Bennas N, Alba-Tercedor J, Ribera C, Prat N. 2009. Using community and population approaches to understand how contemporary and historical factors have shaped species distribution in river ecosystems. Global Ecology and Biogeography 18:202-213.

Bonada N, Prat N, Munne A, Plans M, Sola C, Alvarez-Cabria M, Pardo I, Moya G, Ramon G, Toro M, Robles S, Aviles J, Suarez ML, Vidal-Abarca MR, Mellado A, Moreno JL, Guerrero C, Vivas S, Ortega M, Casas J, Sanchez-Ortega A, Jaimez-Cuellar 
P, Alba-Tercedor J. 2002. Intercalibración de la metodología GUADALMED. Selección de un protocolo de muestreo para la determinación del estado ecológico de los ríos mediterráneos. Limnetica 21:13-33.

Bonada N, Rieradevall M, Prat N. 2007b. Macroinvertebrate community structure and biological traits related to flow permanence in a Mediterranean river network. Hydrobiologia 589:91-106.

Bonada N, Rieradevall M, Prat N, Resh VH. 2006. Benthic macroinvertebrate assemblages and macrohabitat connectivity in Mediterranean-climate streams of northern California. Journal of the North American Benthological Society 25:32-43.

Bonada N, Zamora-Munoz C, Rieradevall M, Prat N. 2004. Ecological profiles of caddisfly larvae in Mediterranean streams: implications for bioassessment methods. Environmental Pollution 132:509-521.

Boulton AJ. 2003. Parallels and contrasts in the effects of drought on stream macroinvertebrate assemblages. Freshwater Biology 48:1173-1185.

Boulton AJ, Lake PS. 2008. Effects of drought on stream insects and its ecological consequences. In Aquatic Insects: Challenges to Populations, 81-102. Lancaster J, Briers RA (eds). CAB International. Wallingford.

Boulton AJ, Sheldon F, Jenkins KM. 2006. Natural disturbance and aquatic invertebrates in desert rivers. In Ecology of Desert Rivers, 103-153. Kingsford RT(ed). Academic Press. New York.

Bracken LJ, Coxi NJ, Shannon J. 2008. The relationship between rainfall inputs and flood generation in south-east Spain. Hydrological Processes 22:683-696.

Bunn SE, Arthington AH. 2002. Basic principles and ecological consequences of altered flow regimes for aquatic biodiversity. Environmental Management 30:492-507.

Carbonell JA, Gutierrez-Canovas C, Bruno D, Abellan P, Velasco J, Millan A. 2011. Ecological factors determining the distribution and assemblages of the aquatic hemiptera (Gerromorpha \& Nepomorpha) in the Segura River Basin (Spain). Limnetica 30:59-70.

Castella E, Bickerton M, Armitage PD, Petts GE. 1995. The effects of water abstractions on invertebrate communities in UK streams. Hydrobiologia 308:167-182.

Chase JM. 2007. Drought mediates the importance of stochastic community assembly. Proceedings of the National Academy of Sciences of the United States of America 104:17430-17434.

Chinnayakanahalli KJ, Hawkins CP, Tarboton DG, Hill RA. 2011. Natural flow regime, temperature and the composition and richness of invertebrate assemblages in streams of the western United States. Freshwater Biology 56:1248-1265.

CHS. 2007. Estudio general sobre la Demarcación Hidrográfica del Segura. Confederación Hidrográfica del Segura. 
Clarke KR. 1993. Nonparametric multivariate analyses of changes in community structure. Australian Journal of Ecology 18:117-143.

Clarke KR, Gorley RN. 2006. PRIMER v6: User Manual/Tutorial. PRIMER-E, Plymouth, United Kingdom.

Clausen B, Biggs BJF. 1997. Relationships between benthic biota and hydrological indices in New Zealand streams. Freshwater Biology 38:327-342.

Cote IM, Darling ES. 2010. Rethinking ecosystem resilience in the face of climate change. Plos Biology 8:e1000438.

De Caceres M, Legendre P. 2008. Beals smoothing revisited. Oecologia 156:657-669.

Diaz AM, Alonso MLS, Gutierrez M. 2008. Biological traits of stream macroinvertebrates from a semi-arid catchment: patterns along complex environmental gradients. Freshwater Biology 53:1-21.

Dufrene M, Legendre P. 1997. Species assemblages and indicator species: the need for a flexible asymmetrical approach. Ecological Monographs 67:345-366.

Estrela T, Cabezas F, Estrada F. 1999. La evaluación de los recursos hídricos en el Libro Blanco del Agua en España. Ingeniería del Agua 6:125-138.

European Environment Agency. 2008. Energy and environment report 2008. Copenhagen, Denmark.

Feminella JW. 1996. Comparison of benthic macroinvertebrate assemblages in small streams along a gradient of flow permanence. Journal of the North American Benthological Society 15:651-669.

Gasith A, Resh VH. 1999. Streams in Mediterranean climate regions: abiotic influences and biotic responses to predictable seasonal events. Annual Review of Ecology and Systematics 30:51-81.

Grindlay A, Zamorano M, Rodriguez MI, Molero E, Urrea MA. 2009. Territorial transformation and water utilization: hydrological planning scenarios in the Segura river basin. In Sustainable Development and Planning IV, Vols 1 and 2. Wit Press. Southampton, 975-+.

Grindlay AL, Zamorano M, Rodriguez MI, Molero E, Urrea MA. 2011. Implementation of the European Water Framework Directive: integration of hydrological and regional planning at the Segura River Basin, southeast Spain. Land Use Policy 28:242-256.

Hart DD, Finelli CM. 1999. Physical-biological coupling in streams: the pervasive effects of flow on benthic organisms. Annual Review of Ecology and Systematics 30:363-395.

Jacobsen D, Rostgaard S, Vasconez JJ. 2003. Are macroinvertebrates in high altitude streams affected by oxygen deficiency? Freshwater Biology 48:2025-2032. 
Jáimez-Cuéllar P, Vivas S, Bonada N, Robles S, Mellado A, Álvarez M, Avilés J, Casas J, Ortega M, Pardo I, Prat N, Rieradevall M, Sáinz-Cantero CE, Sánchez-Ortega A, Suárez ML, Toro M, Vidal-Abarca MR, Zamora-Munoz C, Alba-Tercedor J. 2002. Protocolo GUADALMED (PRECE). Limnetica 21:187-204.

Jowett IG, Biggs BJF. 2009. Application of the natural flow paradigm in a New Zealand context. River Research and Applications 25:1126-1135.

Jowett IG, Duncan MJ. 1990. Flow variability in New Zealand rivers and its relationship to in-stream habitat and biota. New Zealand Journal of Marine and Freshwater Research 24:305-317.

Kennard MJ, Mackay SJ, Pusey BJ, Olden JD, Marsh N. 2010. Quantifying uncertainty in estimation of hydrologic metrics for ecohydrological studies. River Research and Applications 26:137-156.

Kennard MJ, Olden JD, Arthington AH, Pusey BJ, Poff NL. 2007. Multiscale effects of flow regime and habitat and their interaction on fish assemblage structure in eastern Australia. Canadian Journal of Fisheries and Aquatic Sciences 64:1346-1359.

Kennen JG, Riva-Murray K, Beaulieu KM. 2010. Determining hydrologic factors that influence stream macroinvertebrate assemblages in the northeastern US. Ecohydrology 3:88-106.

Konrad CP, Brasher AMD, May JT. 2008. Assessing streamflow characteristics as limiting factors on benthic invertebrate assemblages in streams across the western United States. Freshwater Biology 53:1983-1998.

Lake PS. 2003. Ecological effects of perturbation by drought in flowing waters. Freshwater Biology 48:1161-1172.

Larned ST, Datry T, Arscott DB, Tockner K. 2010. Emerging concepts in temporaryriver ecology. Freshwater Biology 55:717-738.

Lytle DA, Poff NL. 2004. Adaptation to natural flow regimes. Trends in Ecology \& Evolution 19:94-100.

Mathews R, Richter BD. 2007. Application of the indicators of hydrologic alteration software in environmental flow setting. Journal of the American Water Resources Association 43:1400-1413.

McAbendroth L, Foggo A, Rundle SD, Bilton DT. 2005. Unravelling nestedness and spatial pattern in pond assemblages. Journal of Animal Ecology 74:41-49.

McArdle BH, Anderson MJ. 2001. Fitting multivariate models to community data: A comment on distance-based redundancy analysis. Ecology 82:290-297.

McCune B. 1994. Improving community analysis with the Beals smoothing function. Ecoscience 1:82-86.

McCune B, Grace JB. 2002. Analysis of ecological communities. MjM. Gleneden Beach, OR, USA. 
Mellado A. 2005. Ecología de las comunidades de macroinvertebrados de la cuenca del Río Segura (SE de España), Thesis/Dissertation, University of Murcia (Spain).

Millan A, Abellan P, Ribera I, Sanchez-Fernandez D, Velasco J. 2006. The Hydradephaga of the Segura Basin (SE Spain): twenty years studying water beetles (Coleoptera). Memorie della Società entomologica italiana 85:137-158.

Ministerio de Medio Ambiente (MMA). 2004. Water in Spain. Secretaría de Estado de Aguas y Costas.

Monk WA, Wood PJ, Hannah DM, Extence CA, Chadd RP, Dunbar MJ. 2012. How does macroinvertebrate taxonomic resolution influence ecohydrological relationships in riverine ecosystems. Ecohydrology 5:36-45.

Monk WA, Wood PJ, Hannah DM, Wilson DA. 2007. Selection of river flow indices for the assessment of hydroecological change. River Research and Applications 23:113122.

Monk WA, Wood PJ, Hannah DM, Wilson DA. 2008. Macroinvertebrate community response to inter-annual and regional river flow regime dynamics. River Research and Applications 24:988-1001.

Monk WA, Wood PJ, Hannah DM, Wilson DA, Extence CA, Chadd RP. 2006. Flow variability and macroinvertebrate community response within riverine systems. River Research and Applications 22:595-615.

Naiman RJ, Latterell JJ, Pettit NE, Olden JD. 2008. Flow variability and the biophysical vitality of river systems. Comptes Rendus Geoscience 340:629-643.

Niu SQ, Dudgeon D. 2011a. Environmental flow allocations in monsoonal Hong Kong. Freshwater Biology 56:1209-1230.

Niu SQ, Dudgeon D. 2011b. The influence of flow and season upon leaf-litter breakdown in monsoonal Hong Kong streams. Hydrobiologia 663:205-215.

Olden JD, Poff NL. 2003. Redundancy and the choice of hydrologic indices for characterizing streamflow regimes. River Research and Applications 19:101-121.

Oscoz J, Galicia D, Miranda R. 2011. Identification guide of freshwater macroinvertebrates of Spain. Springer. Dordrecht, Netherlands.

Peck JE, Hong WS, McCune B. 1995. Diversity of epiphytic bryophytes on 3 host tree species, thermal meadow, hotsprings island, Queen-Charlotte-Islands, Canada. Bryologist 98: 123-128.

Pegg MA, Pierce CL. 2002. Fish community structure in the Missouri and lower Yellowstone rivers in relation to flow characteristics. Hydrobiologia 479:155-167.

Picazo F, Bilton DT, Moreno JL, Sanchez-Fernandez D, Millan A. 2012. Water beetle biodiversity in Mediterranean standing waters: assemblage composition, environmental drivers and nestedness patterns. Insect Conservation and Diversity 5:146-158. 
Poff NL. 1996. A hydrogeography of unregulated streams in the United States and an examination of scale-dependence in some hydrological descriptors. Freshwater Biology 36:71-91.

Poff NL, Allan JD. 1995. Functional organization of stream fish assemblages in relation to hydrological variability. Ecology 76:606-627.

Poff NL, Allan JD, Bain MB, Karr JR, Prestegaard KL, Richter BD, Sparks RE, Stromberg JC. 1997. The natural flow regime. Bioscience 47:769-784.

Poff NL, Richter BD, Arthington AH, Bunn SE, Naiman RJ, Kendy E, Acreman M, Apse C, Bledsoe BP, Freeman MC, Henriksen J, Jacobson RB, Kennen JG, Merritt DM, O'Keeffe JH, Olden JD, Rogers K, Tharme RE, Warner A. 2010. The ecological limits of hydrologic alteration (ELOHA): a new framework for developing regional environmental flow standards. Freshwater Biology 55:147-170.

Poff NL, Ward JV. 1989. Implications of streamflow variability and predictability for lotic community structure: a regional analysis of streamflow patterns. Canadian Journal of Fisheries and Aquatic Sciences 46:1805-1818.

Puig MA, Gonzalez G, Soriano O. 1984. Introducción al estudio de las comunidades macrobentónicas de los ríos asturianos: efemerópteros, plecópteros, tricópteros, simúlidos y quironómidos. Limnetica 1:187-196.

R Development Core Team. 2008. R: a language and environment for statistical computing. Vienna, Austria.

Resh VH, Brown AV, Covich AP, Gurtz ME, Li HW, Minshall GW, Reice SR, Sheldon AL, Wallace JB, Wissmar RC. 1988. The role of disturbance in stream ecology. Journal of the North American Benthological Society 7:433-455.

Richter BD, Baumgartner JV, Powell J, Braun DP. 1996. A method for assessing hydrologic alteration within ecosystems. Conservation Biology 10:1163-1174.

Sanchez-Fernandez D, Abellan P, Mellado A, Velasco J, Millan A. 2006. Are water beetles good indicators of biodiversity in Mediterranean aquatic ecosystems? The case of the segura river basin (SE spain). Biodiversity and Conservation 15:4507-4520.

Sanchez-Montoya MD, Punti T, Suarez ML, Vidal-Abarca MD, Rieradevall M, Poquet JM, Zamora-Munoz C, Robles S, Alvarez M, Alba-Tercedor J, Toro M, Pujante AM, Munne A, Prat N. 2007. Concordance between ecotypes and macroinvertebrate assemblages in Mediterranean streams. Freshwater Biology 52:2240-2255.

Sheldon F, Thoms MC. 2006. Relationships between flow variability and macroinvertebrate assemblage composition: data from four Australian dryland rivers. River Research and Applications 22:219-238.

Smakhtin VU. 2001. Low flow hydrology: a review. Journal of Hydrology 240:147186. 
Snelder TH, Biggs BJF. 2002. Multiscale River Environment Classification for water resources management. Journal of the American Water Resources Association 38:12251239.

Snelder TH, Biggs BJF, Woods RA. 2005. Improved eco-hydrological classification of rivers. River Research and Applications 21:609-628.

Snelder TH, Lamouroux N, Leathwick JR, Pella H, Sauquet E, Shankar U. 2009. Predictive mapping of the natural flow regimes of France. Journal of Hydrology 373:57-67.

Stanley EH, Fisher SG, Grimm NB. 1997. Ecosystem expansion and contraction in streams. Bioscience 47:427-435.

StatSoft, Inc. 2001. STATISTICA (data analysis software system), version 6. www.statsoft.com.

Suen JP, Herricks EE. 2009. Developing fish community based ecohydrological indicators for water resources management in Taiwan. Hydrobiologia 625:223-234.

Thoms MC. 2006. Variability in riverine ecosystems. River Research and Applications 22:115-121.

Tockner K, Ward JV, Arscott DB, Edwards PJ, Kollmann J, Gurnell AM, Petts GE, Maiolini B. 2003. The Tagliamento River: a model ecosystem of European importance. Aquatic Sciences 65:239-253.

Vaughan IP, Diamond M, Gurnell AM, Hall KA, Jenkins A, Milner NJ, Naylor LA, Sear DA, Woodward G, Ormerod SJ. 2009. Integrating ecology with hydromorphology: a priority for river science and management. Aquatic Conservation-Marine and Freshwater Ecosystems 19:113-125.

Velasco J, Millan A, Nieser N. 1990. Observaciones sobre la colonización y el ciclo de vida de Heliocorisa vermiculata (Puton, 1874) (Heteroptera, Corixidae) en pequeños estanques del SE español. Limnetica 6:101-108.

Vivas S, Casas J, Pardo I, Robles S, Bonada N, Mellado A, Prat N, Alba-Tercedor J, Alvarez-Cabria M, Bayo MM, Jaimez-Cuellar P, Suárez ML, Toro M, Vidal-Abarca MR, Zamora-Munoz C, Moyá G. 2002. Aproximación multivariante en la exploración de la tolerancia ambiental de las familias de macroinvertebrados de los ríos mediterráneos del proyecto GUADALMED. Limnetica 21:149-173.

Walters AW, Post DM. 2011. How low can you go? Impacts of a low-flow disturbance on aquatic insect communities. Ecological Applications 21:163-174.

Winter TC. 2001. The concept of hydrologic landscapes. Journal of the American Water Resources Association 37:335-349.

Zimmer A. 2010. New water uses in the Segura Basin: conflicts around gated communities in Murcia. Water International 35:34-48. 

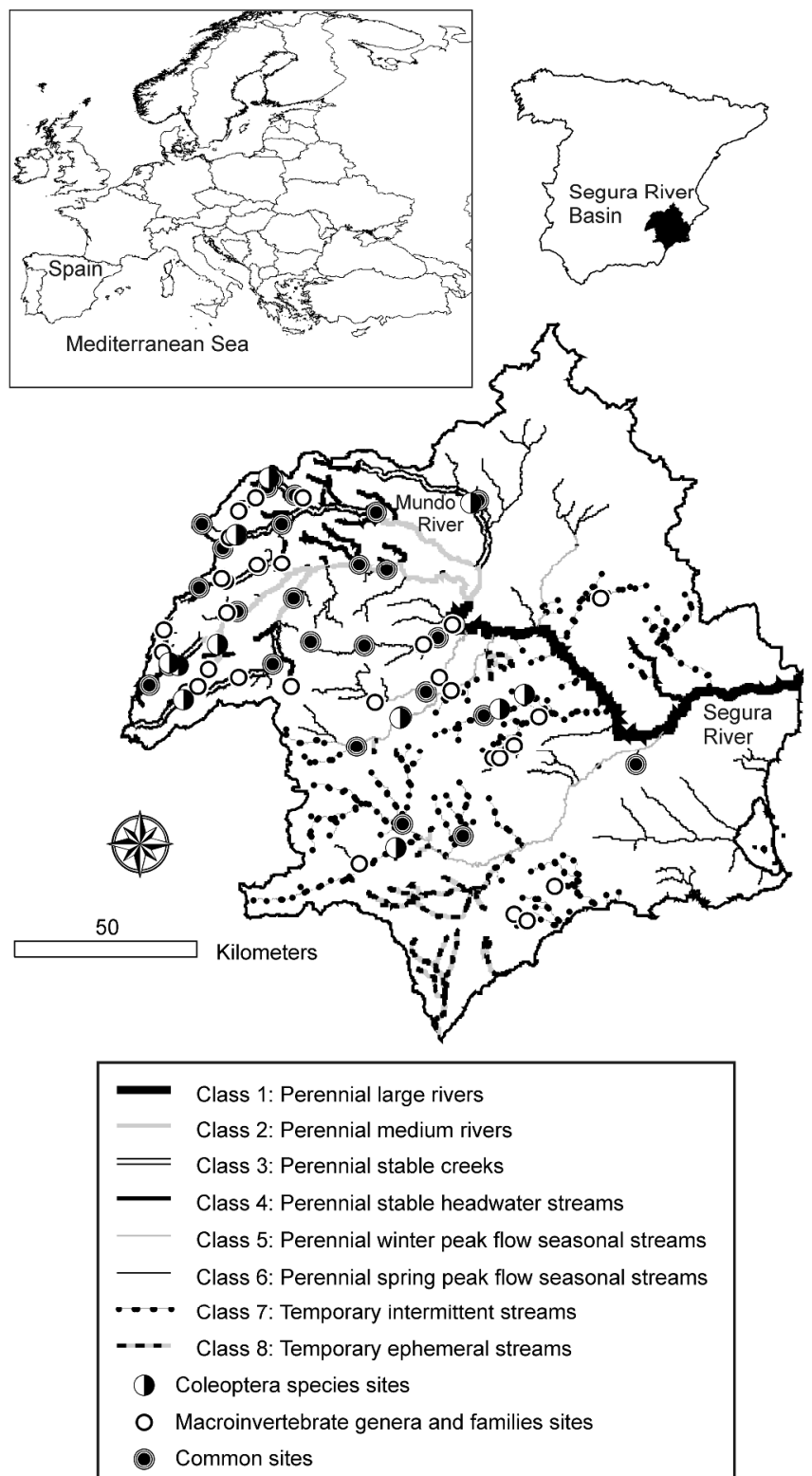

Figure 1. Location of the study area, hydrological classes in the river network and sampling sites. $290 \times 533 \mathrm{~mm}(300 \times 300 \mathrm{DPI})$ 


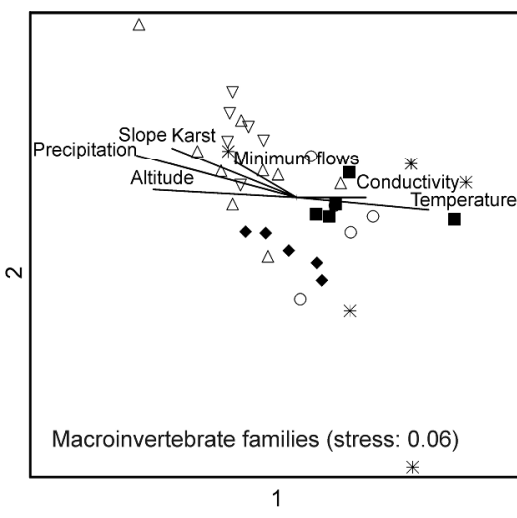

\section{Hidrological class}

2: Perennial medium rivers

$\triangle$ 3: Perennial stable creeks

$\checkmark$ 4: Perennial stable headwater streams

5: Perennial winter peak flow seasonal streams * 6: Perennial spring peak flow seasonal streams - 7: Temporary intermittent streams

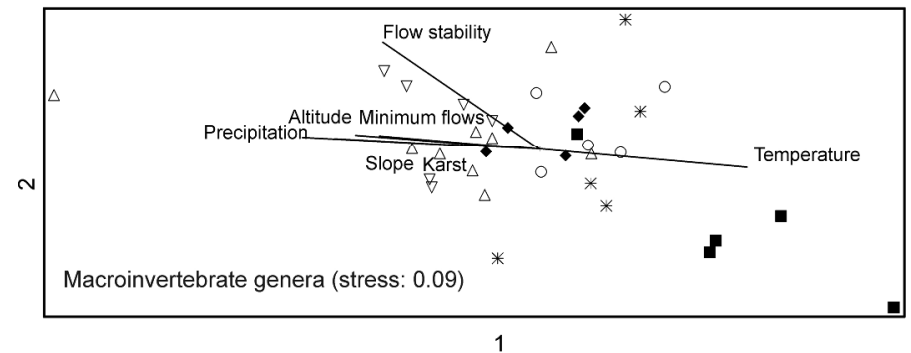

1

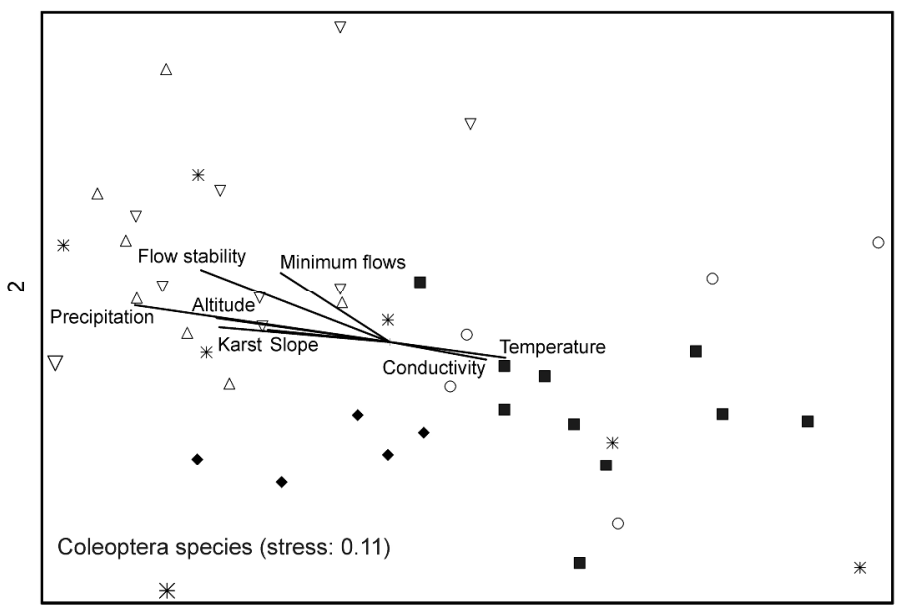

1

Figure 2. NMDS plots of sites for each taxonomic level. The magnitudes of the correlations between the NDMS axes and the hydrological components as well as the environmental variables are shown as vectors. $289 \times 431 \mathrm{~mm}(300 \times 300 \mathrm{DPI})$ 


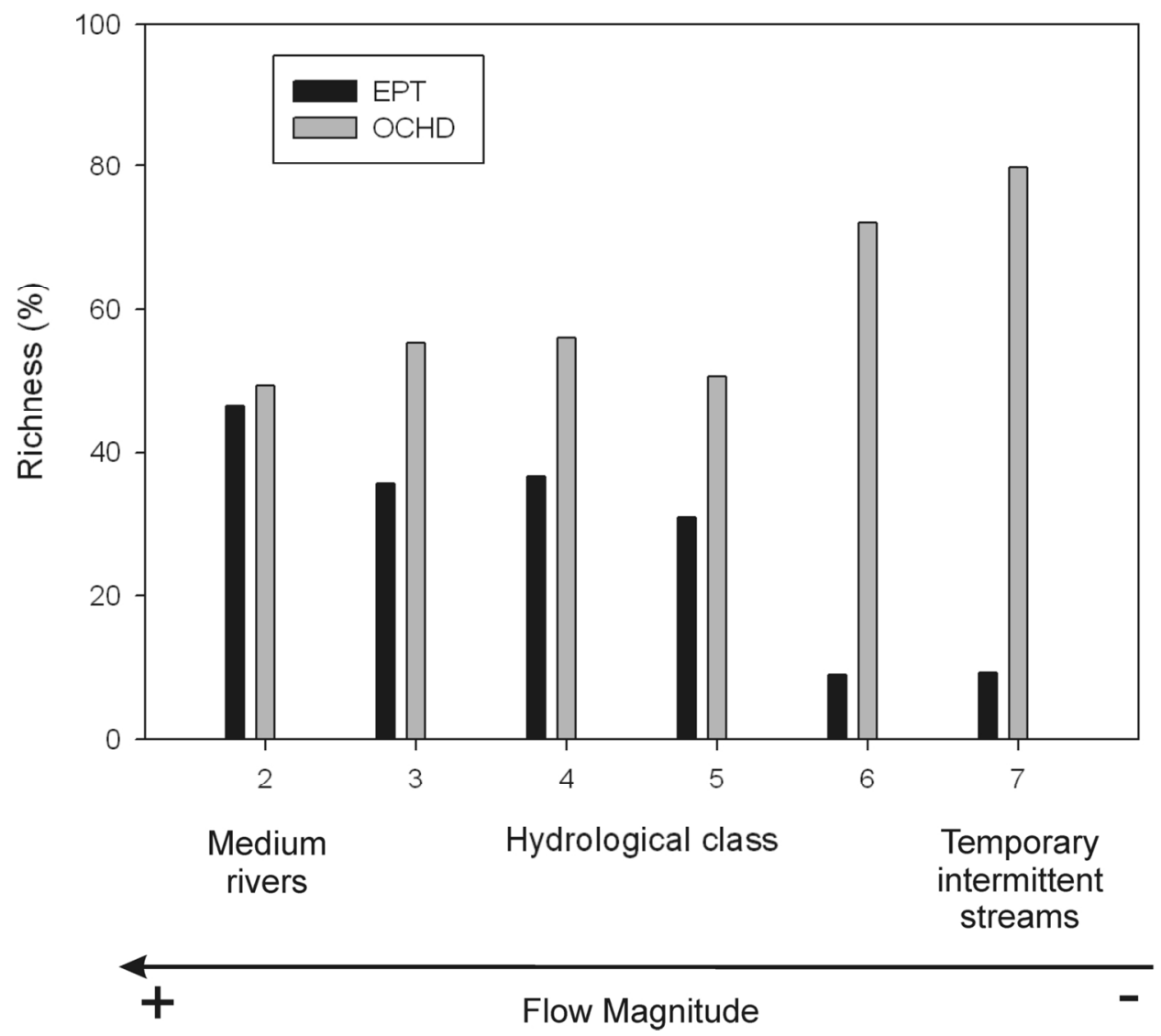

Figure 3. Variation of the percentage of families of the EPT and OCDH groups in the different hydrological classes along the flow magnitude gradient. $140 \times 130 \mathrm{~mm}(300 \times 300 \mathrm{DPI})$ 